University of Rhode Island

DigitalCommons@URI

Open Access Master's Theses

1961

\title{
The Influence of Thyroid Feeding on the Pharmacologic Actions of Certain Monoamine Oxidase Inhibitors
}

Richard N. Carrier

University of Rhode Island

Follow this and additional works at: https://digitalcommons.uri.edu/theses

\section{Recommended Citation}

Carrier, Richard N., "The Influence of Thyroid Feeding on the Pharmacologic Actions of Certain Monoamine Oxidase Inhibitors" (1961). Open Access Master's Theses. Paper 184.

https://digitalcommons.uri.edu/theses/184

This Thesis is brought to you for free and open access by DigitalCommons@URI. It has been accepted for inclusion in Open Access Master's Theses by an authorized administrator of DigitalCommons@URI. For more information, please contact digitalcommons-group@uri.edu. 


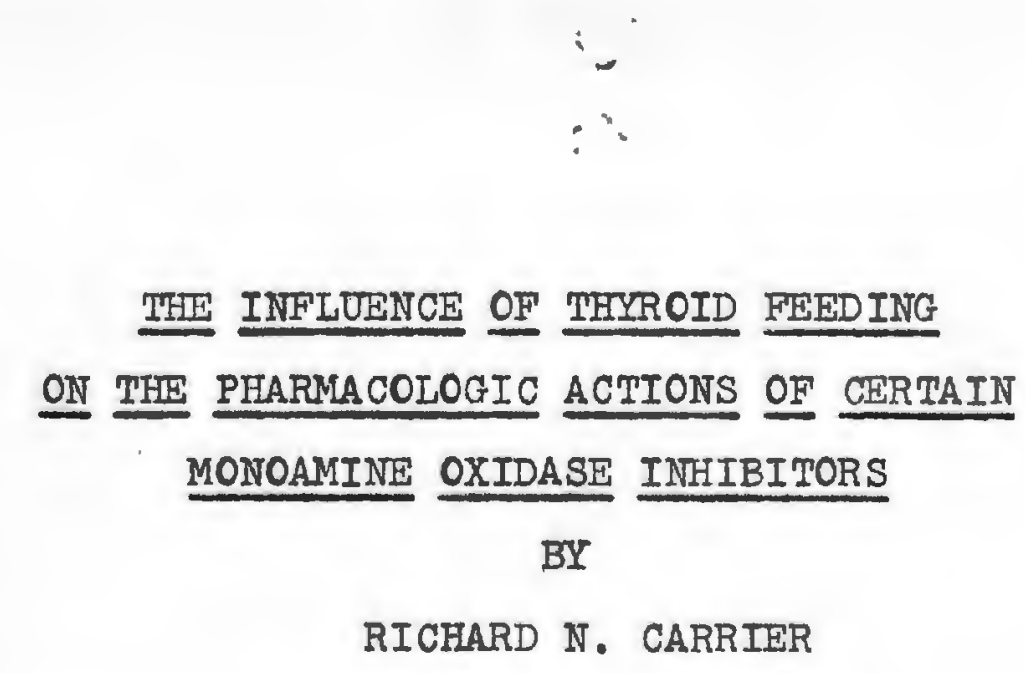

A THESIS SUBMITTED IN PARTIAL FULFILLMENT OF REQUIREMENTS FOR THE DEGREE OF

MASTER OF SCIENCE

IN

PHARMACOLOGY

UNIVERSITY OF RHODE ISLAND.

1961 


\section{ACKNOWLEDGMENT}

The author wishes to express his sincere eppreciation to Dr. P. V. Buday, for his guldance given not only during this study and the preparation of this dissertation but also throughout the entire perlod of graduate study.

He also wishos to thank most sincerely the following: Dr. John J. DeFeo and Dr. Elizabeth Chase, mombers of the graduate comittee; Mr. David R. DeFanti for his ald in the urinary dopamine studies.

The author wishes to express his sincere gratitude to

Dorothy L. Carrier for her unfaling patience, understanding and assistance in preparation of this thesis. 
$\sin \sin \sin$

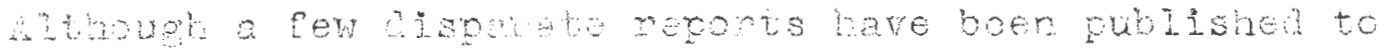

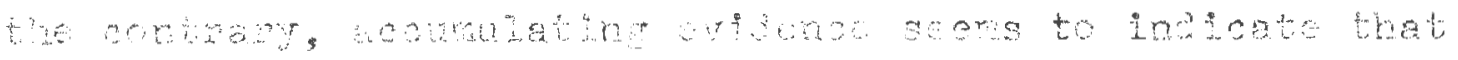

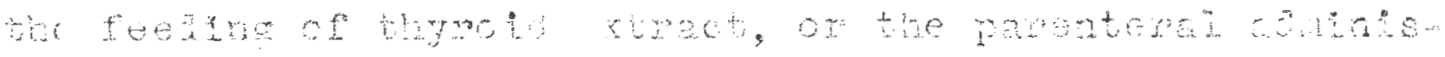

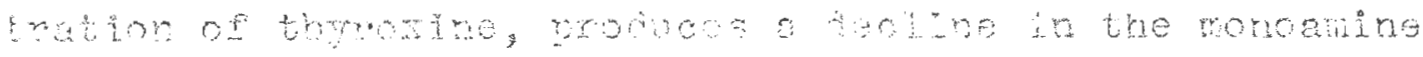

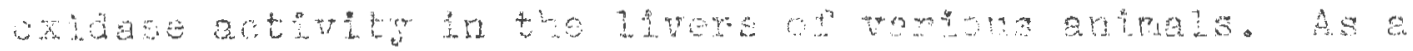
boseruence this arti-enzymto creot end the nesultant

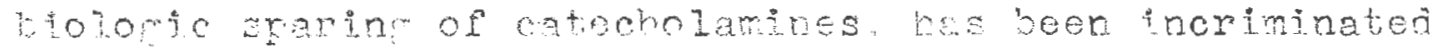
as party resporeshle for the hopraenstivity of byper-

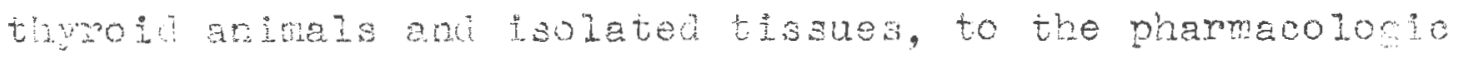
actions of symoathomimetic amines.

Pather recently a class of antj-melancholy orurs, or "roychic enereizers", have been mae clinically avaliable. These agents seem to act as antl-depressants by virtue of their monoame oxidase antagonizing properites.

It was strange, therefore, to note in the litencture that a clinical psychotherapeutic incompatibijity existed between concurrent thyroid and monomine oxidase snbibitor reaication. Pecaliar chaneos in thyroid function, blood prossure, and rlood plucose levels were also notod clinicelly Wh the Iatter medicaments. rhe present research was unertaken, usine bloor lucose, bioo? pressure, and acute and subacute toxicity studies as parameters, to evaluate 
these paradoxical reports. Male, albino rats were employed as subjects.

Iwo ctemically dissimilar, irreversibly actine, monoamine oridase inhibitors, iproniazid (Marsilid) and Mo-911, were selected as test compounds. Phe daily intraperitonea? injection of lproniazid (175 $\mathrm{mg} / \mathrm{kg})$ and $\mathrm{MO}-91 \mathrm{l}(10$ and 25 mg $/ \mathrm{kg}$ ) for a three weak period elicited only inconsequent:al blood sugar changes in both cuthyroid and hyperthyroid animals. Systolic pressures became significantly elevated upon continued injection of either arus, and the pressor effecta were enhanced by feeding a $2 \%$ thyroid diet.

Limited dopamine exuretion stud ios in hyperthyroid rats revealod no particular chenges, whereas massive. daily doses of iproniazic provoked lncressed excretion of the catecholamine approximately 200 to $300 \%$ after fifteen days of enzyme inhibitor treatment. These urjnary results did not parallel the hypertensive effects.

Weight loss, sluggishness, and gross and microscopic evidence of vital organ damage occurred with massive, dally doses of ipronlazid. The acute lethal effects of MO-911 were augmonted by thyroid feeding.

These results seem to suggest strongly that the direct and indirect pharmacologic actions of iproniazid and $\mathrm{MO}-911$, given in high daily doses to rats, are aggravated by a hyperthyroid state; these experimental findings have obvious clinical significance. 
ACKNOWIEDGMENT . . . . . . . . . ........ 111

ABSTRACT . . . . . . . . . . . . . . . . L

LIST OF TABIES . . . . . . . . . . . . . . . 2

LIST CF ILLUSTRATIONS. . . . . . . . . . . 3

INTRODUCTION , . . . . . . . . ....... 4

SURVEY OF THE LITERATURE . . . . . . . . . . . 6

MATERIALS AMD METHCDS。. . . . . . . . . . . 17

RESULTS. . . . . . . . . . . . . . . 25

SUBACUTE STUDIES. . . . .......... 25

GeneraI Observations. . . . . . . . 25

Subacute ToxicIEY . . . . . . . . . . 26

Tissue Pathology. . . . . . . .... 26

Systolic Blood Pressure and Blood Glucose $\cdot 27$

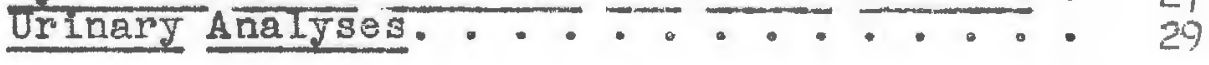

ACUTE TOXICITY STUDIES ........... 29

DISCUSSION OF RESULTS. . . . . . . . . . . 42

SUMMARY AND CONCLUSIONS. . . . . . . . . . . 52

IIST OF REFERENCES . . . . . . . . . . . . 55

APPENDIX .................. 64 


\section{IIST OF TABIES}

TABLE

1 Results of subacute toxicity experiments with iproniazid and MO-911 administered dally................. 31

2 Urinary dopamine levels of iproniazid
and thyrold treated albino rats..... 32

3 Acute toxicity of intraperitoneally administered MO-9II.......... 33

I-A Concentration of standard dextrose solutions and corresponding colorimeter readings . . $65^{\circ}$ 


\section{LIST OF ILLUSTRATIONS}

FI. gure

1. Blood glucose standardization curve......

2. Graph of mean body we1 ght changes of rats under MAO 1nh1b1tor and/or thyrold medication.

3. Blood pressure, blood glucose, and urinary dopamine levels of rats fed $2 \%$ thyro1d.....

4. Effect of da1ly 1ntraperitoneal doses of 1pronlaz1d ( $175 \mathrm{mg} / \mathrm{kg}$ ) on rat blood pressure, blood glucose, and urinary dopamine levels...

5. Effect of da1ly intraperitoneal doses of Mo-911 (26mg/ $\mathrm{kg})$ on rat blood pressure and blood glucose levels................

6. Ef reot of da11y 1ntraperitoneal doses of Mo-911 ( $10 \mathrm{mg} / \mathrm{kg}$ ) on rat blood prossure and blood glucose levels.............

7. Effect of da1ly intraperitoneal doses of MO-811 (26mg/kg) + $2 \%$ thyro1d fording on rat blood pressure and blood Blucose levels.

8. Effect of da1iy 1ntraperitoneal doses of M0-811 ( $10 \mathrm{mg} / \mathrm{kg})+2 \%$ thyro1d food1ng on rat blood pressure and blood glucose levels. .

I-A. Graph10 conf1gurations of the MAO 1nh1bitors employed in the study. . . . . . . . . . . . 


\section{INTRODUCTI ON}

Accumulating evidence seoms to indicate that the foeding of thyrold extract, or the parenteral administration of thyroxine, produces a decline in the monoumine oxidase activity of various animals. Th1s anti-enzymatic offect may result in a blological aparing of catocholamines which might be partig responsible for the hjpersensitivity of hyperthyro1d an1mals and 1solated t1sgues to the pharmacologic actions of sympathomimetio aminos. It has boen shown that monoamine oxidase is intimately involved in catocholamine motaboliom and that 1ts Inhibltion oan alter the clroulating lovels of various pressor and glyoogenolytio amines.

Recently a class of ant1-melanoholy drugs or "paych10 energizers" has boen introduced for olinioal use. These compounds appear to act as ant1-depressants by virtue of the1r ab1lity to 1rreversibly inhlbit monoamine oxidaso activity. The olinioal use of those aubstances tog known to cause a noticoable elovation in the mood of depressod subjects.

other rocent ovidenoe has boon prosonted in the ifterature wh1ch indicates that a olinical poychotherapoub10 incompat1b1l1ty exists with tho oonourrent thyrold and ant1-molanoholy monoamine oxidase 1nhibltor modiation. Peouliar ohanges 
In thyrold function, blood presiure and blood glucose levels such as orthostat1c hypotension and hypoglycemia were also noted clinically with maw of the latter medicaments.

Such oviderce 1ndicates that a olose relationship exists between the in vivo act1vity of the thyrold homone and of the onzyme monoamino ox1dese, and that when the activityeg for these substances are slmultaneousiy altered varlety of pooulfar effeots lo ellolted.

The present resenroh was undertaken to evaluate some of the possible effects of conourrent administration of both deslccated thyrold and monoumine oxidase 1nhibltors in laboratory rodents. Blood gluoose, blood prossure, and acute and subacute toxiofty studies were employed as parameters. 


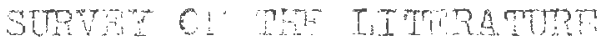

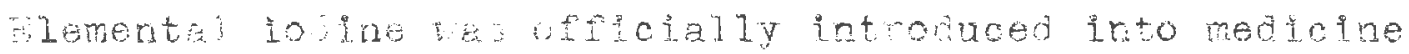

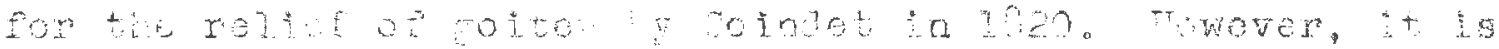
belleved that the chines, many oenturies before the birth

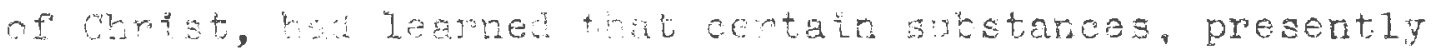

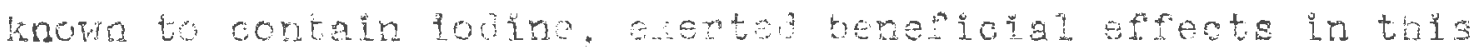

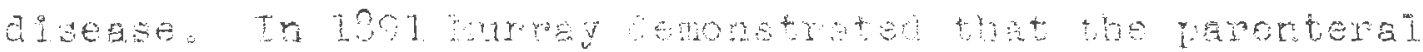

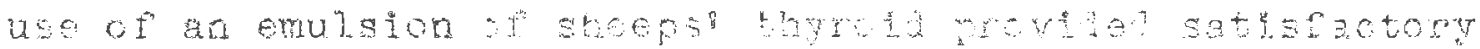

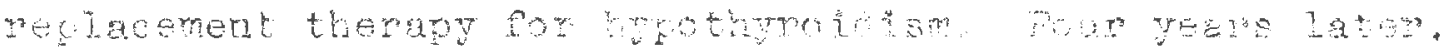

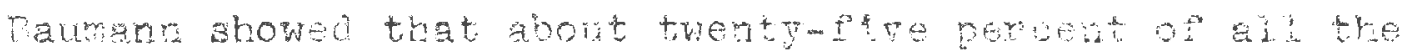

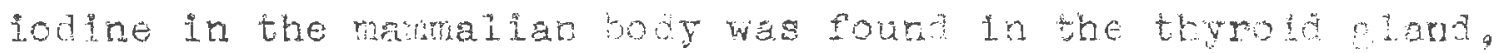
and that it was firmly hound to a colloldal protein-irre material. Oavald later identified tibs as a poton mo

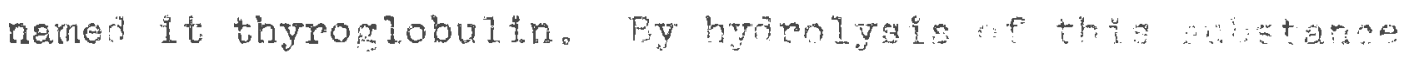
Kencall (1915a,b,c) obtained small. quantitiss of a crystaline, jodnated materia? which was theropeutiogity

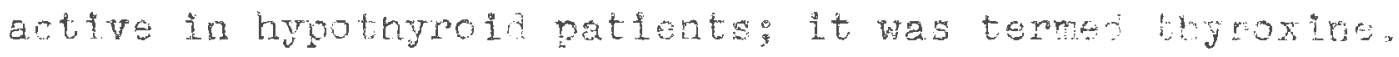
Later Iarington (1926) benteled thyroxine at a derivative

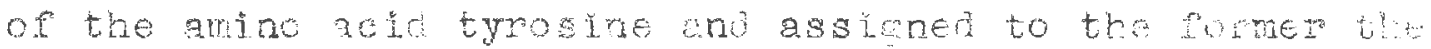
atruotiral formas

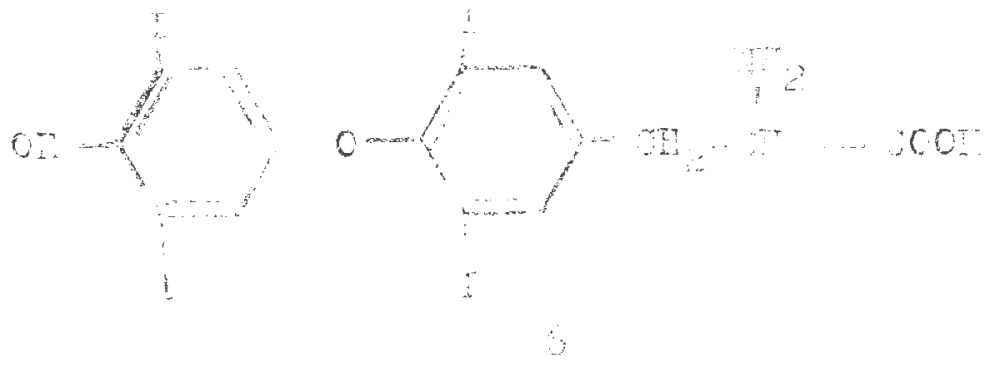




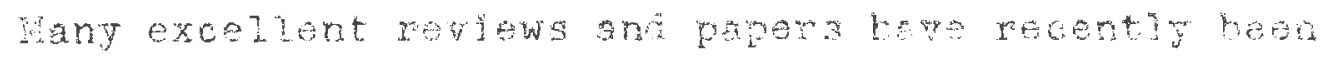

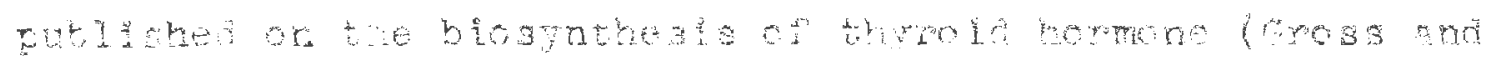

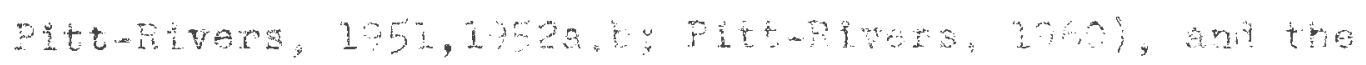
transport and aistribution of this bomone farosa and Putt-pivers, 1953; rogbar, 1960). Suguificant advances have also been made in the chempstry ard physiology of the thyrold stimalating homone (TSif) (White, 146: Albert, 1949; Rawson, 1947; Harris and Woods, 2947; Nelson and Bradloy, 1960; Sonenherg, and Money, 1960; Cariten anc Wraton, 1960), and In the description of the iole thenervous gyatem plays in

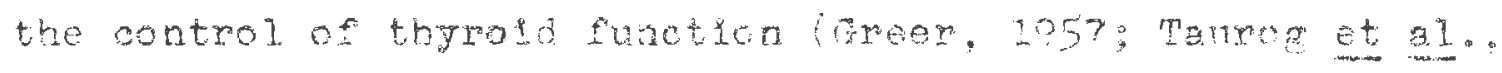
1957\% Greer et al. 1960). Tofomtuately. the mechariam of action of thyroxine and its anglogues has not yet been cleary detined. Blood borne thyroxire can be converted to triludothyronine (TRTT) in the thyroldectomized rat (Gross and Leblond, 1951) and human (Pittwivers et al., 1955), and there is some evidence to indicate that this conversion may be an essential step in forming the "active" hormone (Lardy et al., 1957). A number of compounds have been implicated as the peripheraliy acting hormone. TRIT is Without question, at least in mamals, the more rapid acting (Barker, 1956,1957), and with chronle dosage, the more potent (Gross and PIttarivers, 1954; Roche and Michei, 1955). Several acetyl derivatives of thyroxine, viz., tetraiodothyroacetic acid (TETRAC) and triodoacetic acid (IRIAC) have recently been fsolated; they are less active biologicalig than thyroxine or TRIT (Trotter, 1955; Goolden, 
1956). However, the actual chemical entity responsible for the observed hormonal effects still remains controversial.

It is thought that thyroid analogues may act directly or indirectly on the enzymatic activity of nervous tissue as they do on somatic tissues. Th1s is significant as many facets of brain chemstry and metabolism are now being extensively studied. Recent investigators have outlined the possible metabolic pathways for the synthesis of dopamine, epinephrine (E), and nnorpinephrine (NE), catecholamines which are found extensively in nervous tissue. It is noteworby in this respect that 1-tyrosine is the amino acid precursor of thyroxine as well as of the catecholamines (Blaschko, 1959).

In order to understand the manifold enzymatic effects of the thyrold hormone, investigators have delved into the cellular metabolism of the hormone 1tself. Such studies have shown that there are three possible pathways for the metabolism of the lodothyronines: dehalogenation, oxidation of the alanine chain, and esterification of the phenolic group (Lissitzky and Bouch1lloux, 1957; Roche and M1chel, 1960). It is also belleved that the iodothyronines are oxidatively deaminated to give a keto acld which is subsequently decarboxylated to give the corresponding acetic acid derivatives (Roche et al., 1957; Tomita et al., 1957). In vitro studies have shown these derivatives to be present in skeletal muscle as well as in the liver and kidney. These flndings apparently demonstrate that the oxidative degradation of thyroxine is possible in all tissues (Albright 


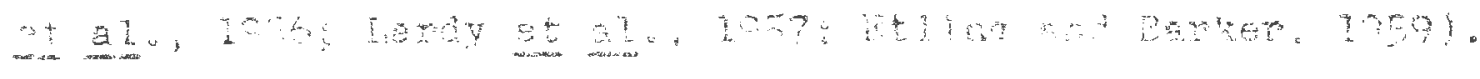

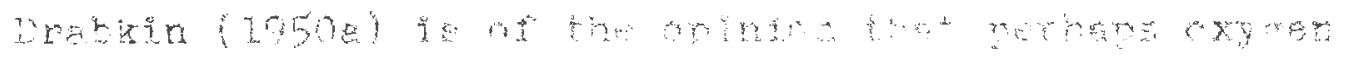

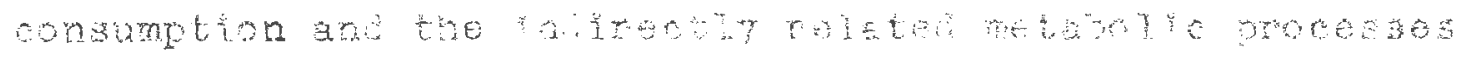
are regulated by the efpect of sodotgrnanes on cytochrome C. Employing rat liver homorenatex Thpton and Nixon (1945) have acnonstrated that crtoobrome oxidase activity is decreased

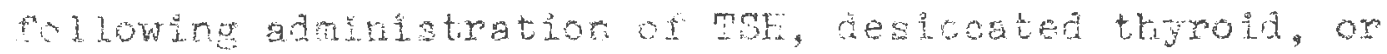
thryorine. Fowever, othor workers have been unable to duplicate

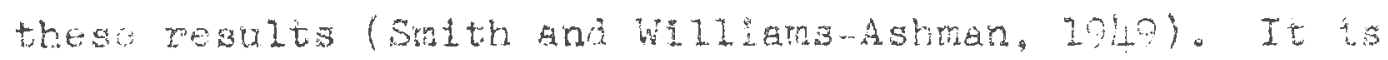

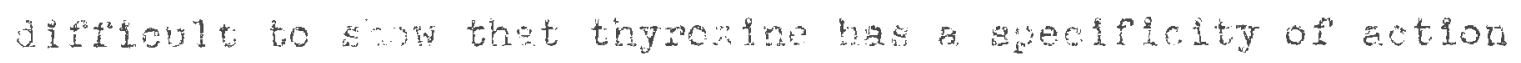

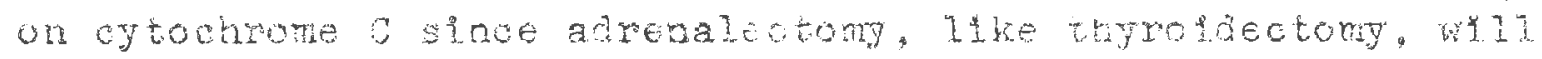

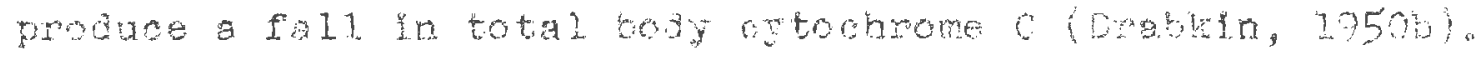

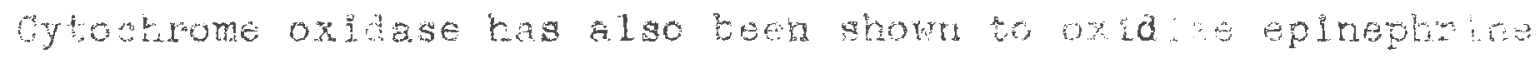

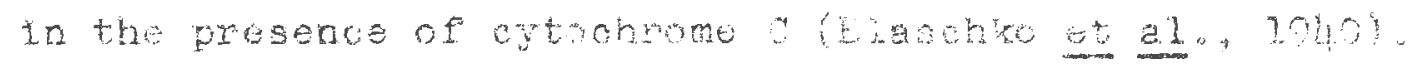

More recentiy the bypothesis has been presentea trat the

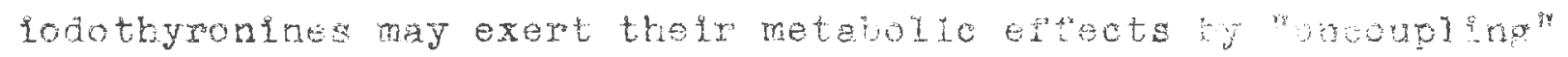
a specific oxldative phosporylatin thus allowin the

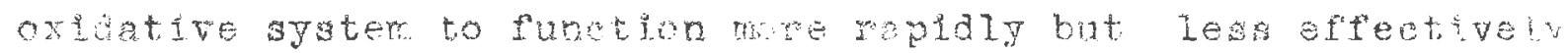
(Lardy and MaleJ, 195/), and ths mat acoount for the hioher

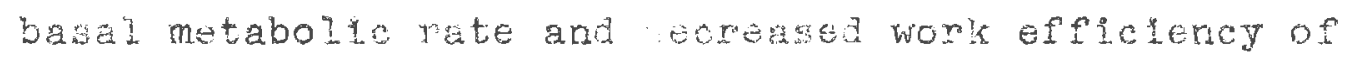
hypertbyroid animals (Lar y, 1957 ). Indeed, th has been found that thyroxine in ritro nepreses the ratio of edterise. i。e. hish energy, phosphorus to oxygen (Leblond and Grad, 1943: Niemeyer et al. 1951; Martius and Hess, 1951,1952: Hoch and Ijpmann, 1953). Dilodothyronine and lodise, bat ast lodide, have a similar action (Xlerperer, 1951). A number of aditional facts support this oxidative 
phosphorylation hypothesis. of significance is the recent observation that mitochondrial swelling and contraction cycles are induced by thyroxine (Tapley et al., 1955). Evidence indicates thet the mitochondrial swelling requires electron transport and this effect is promoted by thyroxine as well as by phosphate, calcium lons, and reduced glutathione, whereas contraction occurs in the presence of adenosine triphosphate (Lebninger, 1960). This becomes important in the Ilght of the fact that there is a decreased oxygen consumption in enlarged mitochondria, which is in turn attributed to a decrease in adenosine triphosphate levels (Aebi, 1952). However, a great deal of opposition has arisen to the oxidative phosphorylation hypothesis since the thyroxine concentration to produce these effects in vitro is several orders of magnitude greater than that nomally present in vivo. In adition, In vitro responses have not been consistent and sufflciently reproductble (Rawson and Sonenberg, 1959). Thyroid hormone exerts a significant action on the mammalian nervous system. The nervous instability of patients Wth Graves' disease (exophthalmic golter) has been noted since the disease was flrst recognized (Grave, 1835; Parry, 1835; von Besedor, 1840). Similarily, the apathy and slugglshness of cretins has been know for centuries (Major, 1939). Furthermore, various psychoses have been assoclated with both hyperthyroldism and myxedeme (Dunlap and Moersch, 1935; Jamieson and Wall, 1936). Voluntary muscle reflexes are diminished in thyroldectomized animals 
(Er,dy, $1941 a, b)$, and electroencephalograms of athyrootic patients show diminished voltage, slow frequency, and an absence of cortical alpha waves. In nyperthyroid patients the alpha rhythm is increased (Bertrand et al., 1938). Some correlation has been found between the basal metabolic rate and the rate of alpha wave emanation from the nerrous system (Ross and Schwab, 1939). In contrast to the effects on general metabolism, most investigators have bean unable to detect a change produced by thyroxine in the cate of oxyzen consumption of brain slices (Farington, 1944), , it is felt that alpha wave frequency measurements during artificlally induced hyperthyroldism are undirect measures of carbohydrate metabolism in the brain (Rubin et al., 1937). Bowman (1925) and Hoskins (1946) found lowered basal metabolic rates in a large number of schizophrenic patients. They also described unusually high clinical tolerance to the effects of dried thyrold. Brody and Man (1950), however, have reported normal serum protein-bound lodine levels in similar patients while Cranswick (1955) has deacribed abnormally elevated thyro1d uptakes of $\mathrm{I}_{131}$ in a majority of schizophrenic patients. The administration of TRIT to various psychopathologically affected, but euthyro1d, patlents evokes the appearance of formerly latent or absent hostile emotions and sexual unrest (Flach et al., 1960). Signiflcant emotional changes, however, were not always observed (Flacb et al., 1958). Paralleling the advances in thyroid research, stimulated by the introduction of radoactive lodine, has been the progress 


$$
12
$$

which bas been made in neurocheruistry as a consequence of the introduction of iproniazia, a "psychic enereizer". rihis hycarine derivative was cripinaily synthesized by Roche Laborgtorles for the chemotherapy of tuberculosis. It was soon evident, however, that the greatest value of the drug: lay in its ability to create a sustained feeling of "wellbeing" in psychicallydepressed patients (Crane, 1956). Selikoff and others (1953) attributed this effect to central stimulation. Zeller et al. (1952a) discovered that iproniazid was a potent inbibitor of the intracellular enzyme monoamine oxidase (MAO), an enzyme incriminated in the mode of action of certain anti-depressant orrugs.

MAO has been found in significant amounts in liver, kidney, and other organs and tissues (Richter and Tingey, 1939), and is present chiefly in mitochondrial and microsomal cell fractions (Cotzlas and Dole, 1951; Hawkins, 1952). Enzymatic studies have shown that iproniazid irreversibly blocks MAO activity in the autonomic nervous system, brain, liver, and kidney, both in vitro and in vivo (Zeller and Barsky, 1952; Zeller et al., 1952b).

The psychiatric value of iproniazid and other MAO Inhibitors has been clearly demonstrated and has led to the introduction of a large number of chemically heterocenous ant1-depressants (Delay and Bulsson, 1958; Geyer, 1958; Tobin et al., 1959). Evidence indicates that MAC is important in the metabolism of serotonin (5-HT) and the catecholamines, and that the anti-depressant effects elicited by the MAO 
Inhibitors are related to the central nervous system changes In these monoamines (Pletcher, 19, Jdenfriend et al., 1957; spector et al., 1958). The relation of MAO to catecholamine metabolism was first rocognized by Blaschko gt al. (1937) who demonstrated that the enzyme oxidatively deaminated epinephrine. Brodie et al. (1959) have shown that after single, large, oral doses of MAC Inhlbitors both 5-HT and NE levelg increase slgniflcantly in dog and rabbit brain. However, contrary to previous reporta it has been found that O-methylation probably constitutes the major patbway for the catabolism of this amine (Armstrong et El., 1956; Axelrod, 1957). MAO has also been incriminated in the metabolism of tyramine and dopamine (Spector et al., 1959; Resnick, 1959).

It is known that thyroid hormone potentiates the action of eplnephrine on oxygen consumption and basal metabolic rate (Lardy, 1957), and heart rate (Gravenstein and Thier, 1960). This potentiation of the activity of epinephrine on the resting blood presgure (Gerlei, 1938) and on isolated arterles (Smith, 1954) has been explained as the ability of thyroxine to elicit a fall in tissue amine oxidase levels. Likewise, Burn and Marks ( 1935 ) showed that thyroldectomized rabbits were slightiy less responsive to epinephrine induced hyperglycemia than normal animals. More recent experiments have shown that feeding of desiccated thyro1d causes hepatic MAO of rabbits to diminish, whereas thyroidectomy causes MAO activity to rise. The rise in blood glucose caused by injected epinephrine is greater in rabbits fed thyroid extract, 


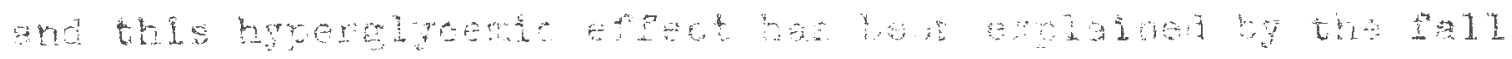

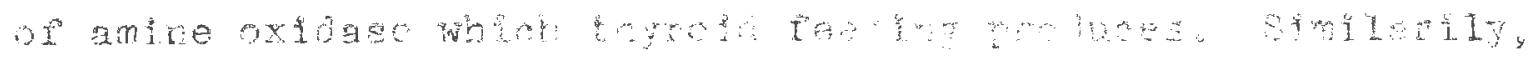

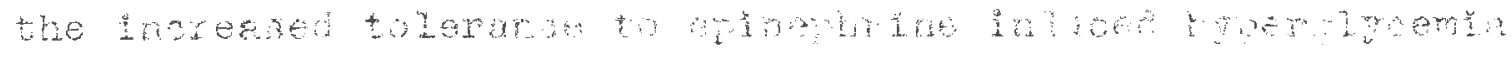
in thy doctomized rabbits ha been explatined by the rise of

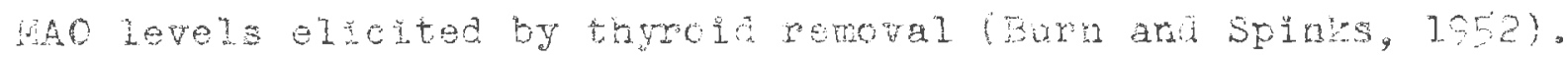

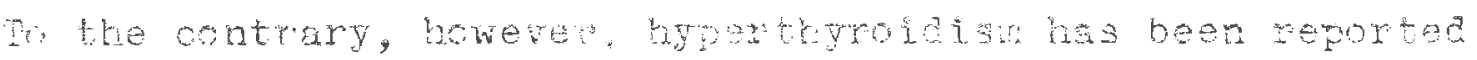

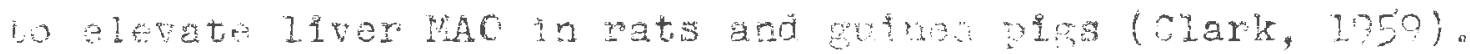

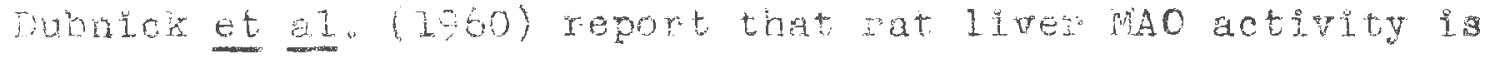

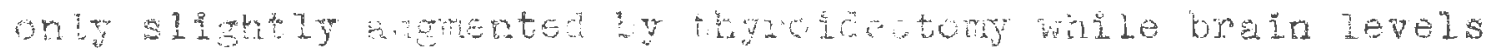
semaln unchanses.

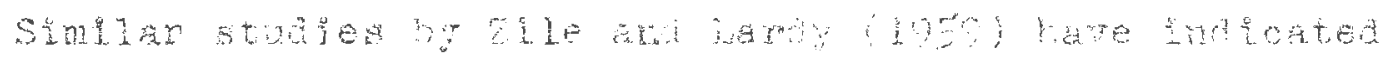

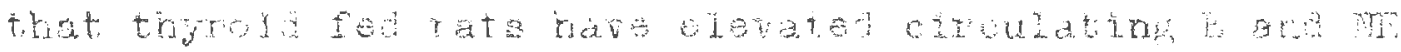

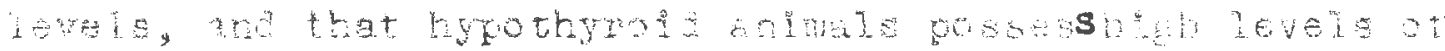

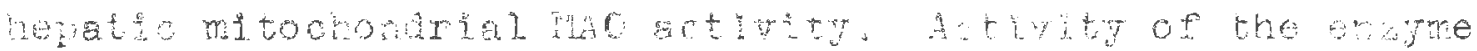

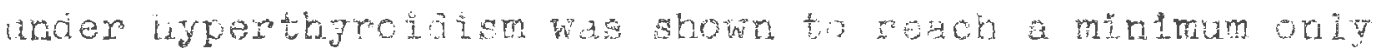
after twelve days of treatment. Gemination of thyol Ieeding al lowed MAO activity to return to nomal stath fourtegr days, and conseruently tho rerersible decreges in MAC activity by thyroid homone was consiaered to be an Indrect suppression of the enzyme, perhaps through a resulation of synthesis of the enzyme. This supposifion is also shared by others (ozaki et al., Jo6 ) . Ir contrast to the worik of Splnks and Burn (1252), it has beer shown that there is no correlation in HAO actipty andolood sucer lovels in the frog (Smith, 1960).

The distinct psychotropic actions oi thyroxine and iproniazid proves interesting when one condider the clinical 


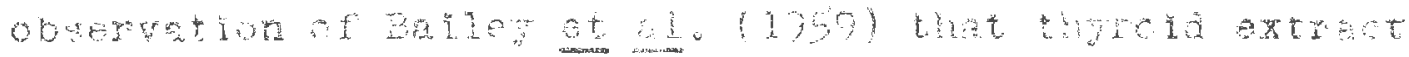

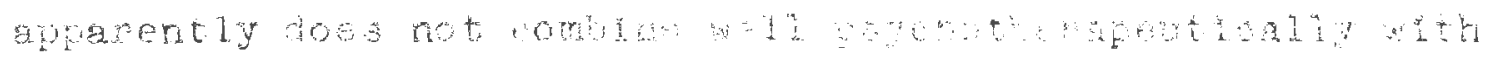

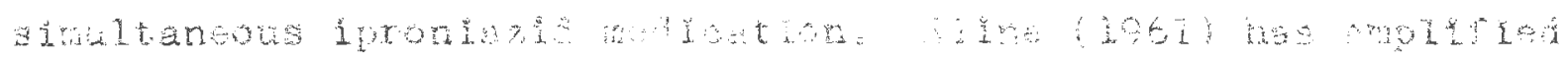

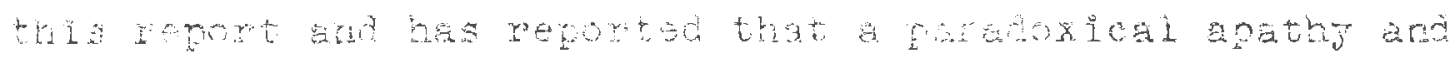

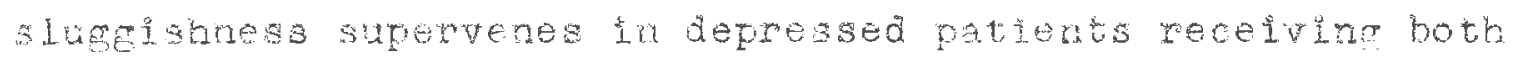

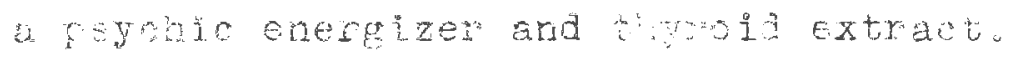

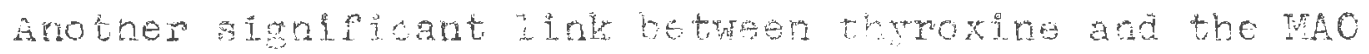
Inhbitor action is conoernod with tbar respective efficacy

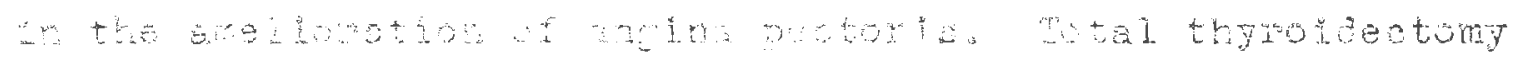

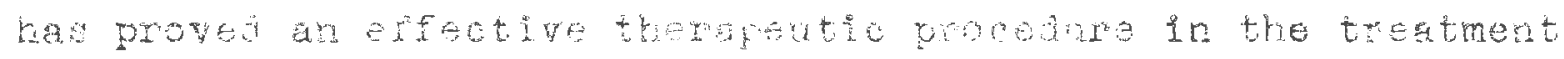

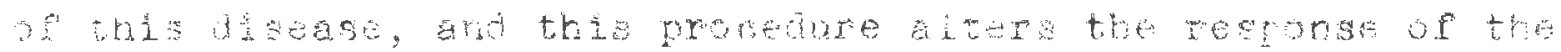

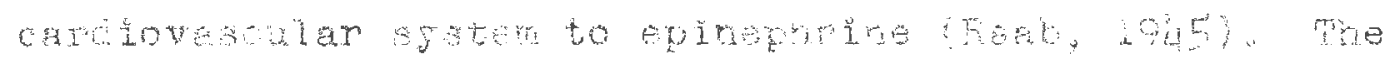

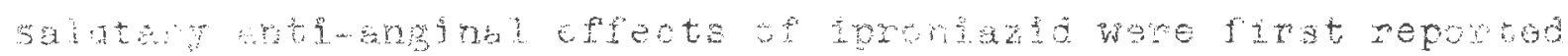

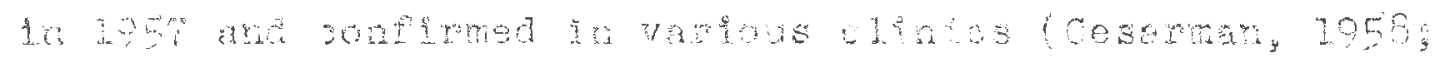
Cosio, 1359; Schwelzer, 1959, Mastar ano Donoso, 1959)。 Several hypotheses hase ben postulated as to the mechaph

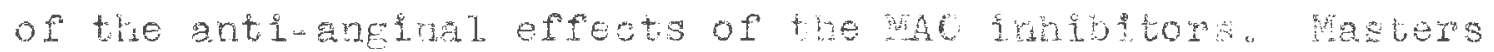

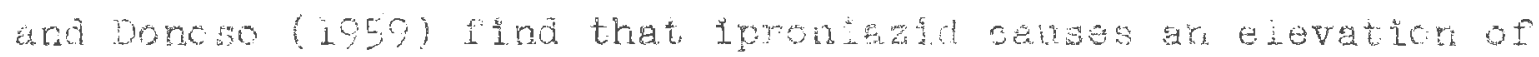

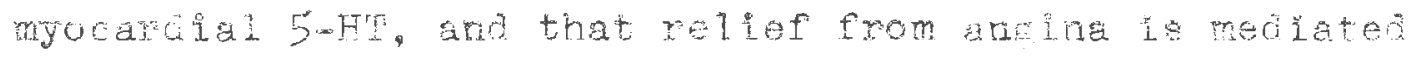
through myocardial and cerebral autonomic nevves cesarman $(1957,1959)$ proposes that iproniazid may influence cardiac metabolism through some enzymatic mechanism. Pletcher and Eellmont (1950) have aemonstrated that a strixing Ino in myocardial catecholamines occurs in iprontazid treated gunea Bigs, aro they have related these changes to the thomapento eftecto of this compound In certain hypotinyolid patients. bowever, thyroid in doses as low as eight to sixteen 
milligrams has produced severe anginal pain. With concomitant therapy with an MAO inhibitor, it was found that thyrold cosage coul be gradually increagea to relleve the myzedema without ageravating the cardiovascular complaint (Wolffe and Shubin, 1959).

The administration of desiccated thyrold has been shown to elevate the cardiac output whereas myxedematous patients show a subnormal output (Schelnberg et al., 1950). Hyperthyroidisn appears to increase the mean systolic ventricular pressures and the resting blood pressure of rabbits (Fullerton and Harrop, 1930; Spinks, 1952). In contrast, ipronlazid regardiess of 1 ts monoamine sparing effects, has been shown to cause severe orthostatic hypotension (Randall, 1958) possibly through ganglionlc blockade (Gertner, 1959). It has, for this reason, been suggested for the treatment of hypertension (Harnes, 1958). 
MATERIALS AND METHODS

Subacute Studies

Sixty male, albino rats of the wistar strain, ranging in welght from $170-210 \mathrm{~g}$, were divided into 10 groups of 6 anlmals each (Table 1). Each group was housed separately. The environmental temperature was maintained between $250-20^{\circ} \mathrm{C}$. Inltialy, all 60 rats were placed on a control diet consisting of water ad 11b. and speclally repelleted tablets of Purina Laboratory chow for 7 days. On the elghth day, groups I through $V$ here continued on this eontrol diet while groups VI through $X$ were placed $n$ a lmilar diet which, in addition, contalned $2 \%$ powdered Thyrold $U_{0} S_{0} P_{0}{ }^{2}$ The animala were then maintained on these respective diets for an additional 21 days. To prevent vitamin A deflclt, due to increased utilization of this vitamin during the thyroid treatment (Hague ot al., 1948) and to retard welght loss (Logaras and Drumond, 1938), all animals were glven 3 drops of Oleum Percomorphum 3 (vitamin $A$ and D) oraliy every third day of the study. On the elghth day, normal blood pressure and blood glucose levels were taken. Subsequent blood pressure levels were recorded dally, and blood sugars were measured overy third day.

1 Ralston Purina Co., St。Louls 2, M1ssour1.

2 Amour Laboratories, Kankakee, IIlinols.

3 Mead Johnson and Co., Evansv11le 2l, Indlana. 
Diet. The incorporation of thyrold extract into the diet was considered the most satizfactu method of hormone treatment (Anderson et a1., 194, although it presented certain technical difficulties which required the extemporanoous repelleting of the anlmel feed. The food product as manufactured 4 contains no exclpient to bind the fibrous meal. Instead, molsture in the form of steam is added directly to the $\mathrm{mix}$, and the molstened meal is forced through a die under high pressure. Our lacilities did not permit high compression tableting so that molsture alone was not a sufficient adhesive for the fibrous and resilient meal. Starch, dextrin, sucrose, glucose, lactose, or other similiar carbohydrate-like exclplents commonly emplojed to prevent crumbling, were Inappropriate to use as these would have a tendency to modify certain metabolic effects of the thyrold treatment. A method found simple and expeditious to produce an acceptable remade chow tablet, using Iimited and easily accessible equipment, was to crush the hard, brittle pellets by use of a Wlley laboratory mili 5 , passing the coarse material thence through a Mikro Samplmili 6 (model 579A) to give a number 60 powder or finer. To each $100 \mathrm{~B}$ of this powder was added $40 \mathrm{ml}$ of a warm,

4 Letter from Speclal Chows Research Division, Research Department, Ralston Purina Co., St. Louls 2, M1ssour1.

5 Standard Model Number 1, distributed by A.H. Thomas Co., Phlladelphla 5, Pennsylvanla.

6 Pulverizing Machinery Co., Sumit, New Jersey. 
freshly prepared, gelatin-acacla solution made by dissololing $10 \mathrm{~g}$ of Gelatin (granular) U.S.P. and $1 \mathrm{~g}$ of Acacla (powder) U.S.P. In $100 \mathrm{ml}$ of boling distilled water. The biader and powders were then mixed thoroughly to form a damp mass. The latter was then sifted through a number 10 mesh brass screen to form granules. These particles were then passed through a number 20 mesh screen to obtain a finely granulated mass.

To prepare a $2 \%$ thyro1d diet 1 was necessary to readjust the formulation so that $200 \mathrm{~g}$ of the mass contained $90.76 \mathrm{~g}$ powdered chow, $2.00 \mathrm{~g}$ powdered thyro1d, and $7.2 \mathrm{k} \mathrm{g}$ of exclplent. These substances were propared and mixed as prevlously describod. Using a hand driven, single punch, Stokes tablet machine (model A3-Eureka) ${ }^{7}$ with $2.27 \mathrm{~cm}$ standard concave punch and die set for maximum fill ( 1.09 $\mathrm{cm})$, the damp granulation was compressed Into 0.5 \& convex tablets having $2.0 \mathrm{~mm}$ edge thlckness. The pressure on the punch approximated 7.5 tons per square inch. The tablets were allowed to dry and harden thoroughly at amblent room temperature (approximately $21^{\circ} \mathrm{C}$ ) for 36 hours or longer.

Drugs. Elght of the 10 groups of rodents recelved daliy intraperitoneal injects of a MAO inbibitor for the 21 days concomitant with the thyrold or control diets. The remaining two groups were used as controls (cf. Table I). Animal groups I, II, VII, and VIII were injected with

7 F.J. Stokes Corp., Phlladelphia 20, Peansylvania. 
1sonicotingl-2-1sopropylhydrazine phosphate (iproniazid) ${ }^{8}$, a hydrazlde enzyme inh1bitor, an groups III, IV, IX, and X were infected with $\mathrm{N}$-benzJl-N-methyl-2-propynglamtne hydrochloride $(M 0-911)^{9}$, a non-hydrazide inhibitor, in the doses as outined in Table 1. The structural formulae of these drugs are given in Figure I-A (Append1x). The solutions for injection were prepared by dissolving the respective salts in isotonic saline. The $p$ H of the solutions approximated 3.5 .

Mothods. Ind1rect systol10 blood pressures were determined by the method of Kersten et al. (1947) using a PhotoelectricTensometer 10. All roadings wore taken to the closest $5 \mathrm{~mm} \mathrm{Hg}$ and were recorded as direct instrument values.

Blood glacose levels were determined by the colorimetric method of Nelson (2944) as modffied by Somogy1 (1945). Samples were read in optlcal density unite on a Bausob ana Lomb Spectronlo 20 colorimeter, typo 39-24-1011, using the special $\frac{1}{1}$ Inch dameter cuvette a provided by tho manufacturer ${ }^{22}$. To prevent reading srrors, the cuvettes were callbrated using a standard $\mathrm{CuSO}_{4}$ solution. The colorimeter was standardized by using known amounts of dextrose diluted

8 Generoualy supplied as Marsilld by Dr. Robert E. Dixon, Roche Laboratories, Nutley 10, New Jersey.

9 Generously supplied by Dr. G.M. Everett, Abbott Laboratories, North Chlcago, Illinols.

10 Metro Industries, Long Is land City 6, Now York.

II 3ausch and Lomb Opt1cal co., Rochester, New York.

12 spectronic 20 test tubes \# 33-29-27, Bausch and Lomb Opt1cal Co., Rochester, New York. 
to $100 \mathrm{mi}$ with glas astilled water. Seven conentrations were employed and rangea from 60 to $210 \mathrm{~m} / \mathrm{l}$ o $\mathrm{ml}$ (Table I-A). Wivo readings of each concentration were made by takine 0.1 ml. of the sample and ading it to $1.5 \mathrm{ml}$ of diatilied water. To this mixture was added $0.2 \mathrm{ml}$ of $5 \% \mathrm{ZnSO}_{4}$ and $0.2 \mathrm{ml}$ of $0.3 \mathrm{~N} \mathrm{Ba(OH})_{2}$. All chemicals were of rearent quality. The suspension was centrifuged for 5 minutes at 4000 rpmis. one ml of the supernatant liquid was then pipetted into a Folin-wu sugar tube which had been previously fil.led with $1.0 \mathrm{ml}$ of alkeline copper tartrate solution. The nixture was heated in boiling water for 20 minutes and then conled in runaing tap watcr for 2 minutes. To the cooled solution was adaed $1.0 \mathrm{~m}$ of arsenomolybdate roagent and the solution was nixed and allowed to stand for approximately 2 minutes. After adjustino the volume of the resulting colored solution to $8.0 \mathrm{ml}$ with distilled water the solution was placed into the ouvette. A blank determination was prepared in the same manner usine O. I ml of glass distilled water in lien of the dextrose. The blank cuvette was then placed in the colomimeter and the instrument adjusted to an optical density of zero and a wave length of $500 \mathrm{mu}$. The sugar sample was then substituted for the blank anc the resultant optical density read. The mean of the 5 readings for each sample was plotted against the concentration (Table I-A; Iigure 1 ). The resultant plots were then adjusted using the line regression methol as described by ostie (1956) and the mathematicaligr derivod Ine vas plotted. 
Blood samples were obtained d1 ret Intracardac puncture with a $0.25 \mathrm{ml}$ syringe and a number $<7$ paupe- $\mathrm{I}$ inch hypodermic needle. In order to obviate blood samplina difficulties and possible epinephrine release (Weil, 1952), the samples were taken while the animals were lightly anestbetized with pentobarbital sodium $(20 \mathrm{mg} / \mathrm{kg})$. To eliminate variances in blood glucose levels, due to differences in the food intake of the animals, all animals were fasted for 17 nours prior to the blood collections. The blood samples were processed in the forementioned method employing a blank with gach group of samples. The blood glucose concentration of each sample was determined from 1nstrument readings and che respect - concentration in mg/100 mL read from the ine graph (Figure 1).

Histologic Studies. Samples of liver, klaney, spleen, and thyrold tissue were rome ved from one rapresenuativo animal in each group gtudied. These tissues ware flxed in Bouln"s solution, dehydrated, cleared in xylo1, mounted in paraffin, and sliced into 1012 sections. The sections wero stalned with hematoxyin and oosin and oxamined for general pathology.

Urinary Dopamine Stuaies. Twenty-four hour urine samples from groups II, $V$, and $X$ were collected in $2 \mathrm{~N}_{2} \mathrm{SO}_{4}$ on the eighth and fiftesnth day of the studies. The pooled samples were filtered and processed for extraction of catecholamines (Crawford and Law, 1958). An allquot of the urine extract was passed through a strongly acidic, cationic 
exchange resin (Dowex 50W-X8, Nat form) ${ }^{13}$ and the dopamine was eluted with $8.0 \mathrm{ml}$ of $2 \mathrm{~N}$ Hi (Bertler et al., 1958)。 Urinary dopamine levels were determined is the trinydroxylndole method of Carlsson and Waldeck (1958) employing an Aninco-Bowman spectrophotofluorometer 14 . Acute Toxicity Studies

As a consequence of the subacute MAO inhibitor and thyroid interaction studies, an apparent augmentation was observed in the mortallty of hyperthyrold rats recelving high dalig parenteral doses of the hydrazlde (1proniazid) or the non-hydrazlde (M0-911) enzyme inhibitor (Tablo 1). To ovaluate this possible hormonal aensitization, 73 malo rats (W1star strain) ranging in inftial wolght from 133-190 g wero omplojed in an acute mortallty study. Four groups of fasted animals ( $172 \mathrm{~g}$ moan welght), 8 animals to a group, proviously fed on a 7 day control diet ad 11b. 15 wore injected Intraperitoneally with doses of M0-91I differing by .03 log: un1ts (Table 4). Four other groups (127 g mean weight), previousiy made hyperthyrold by a 7 day desiccated thyrold $(2 \%)$ ad 21b. diet 16 , were treated in an 1dent1cal manner. Nine additional byperthyrold rats $(230 \mathrm{~g}$ mean welght) were ingected solely with normal physlological saline solution and served as controls. All antmals were housed at a temperature of $25^{\circ}-27^{\circ} \mathrm{C}$

13 J.T. Baker Chem1cal Co., Ph1ll1psburg, New Jersey. 14 American Instrument Co., Inc. S1lver Spring, Maryland.

15 Control det was identical to that used in the subacute study. study.

16 Thyrold det was 1dentical to that used in the subacute 
and were provided prior to MAO inhibitor medication with oral vitamin $A$ and $D$ supplementation at 3 day intervals. 


\section{RESULTS}

SUBACUTE STUDIES:

General Observations. The MAO inhibitor medicated animals exhibited somewhat legs motor gctivity and seemed easier to handle than control animals. Within 3 to 4 days, all thyroid fed rodents showed considerable irritablifty, whereas the hyperexcltability was less apparent when thyroid was combined with the enzyme inhibitor mealcation. The augmented apatby in he latter instances became increasingly pronounced with continued drug administration.

Food and water consumption decreased with iproniazid therapy but was less pronounced with M0-911. Thyrold fed controls ssemed to increase their intake twofold, while MO-911 and Ipronlazid treated, hyperthyroid animals seemed to be restrained in their feeding habits. The demise of drug treated animals was always preceded by complete cessation of food consumption. Mean body welghts of euthyroid subjects under iproniazid medication fell steadily while the welghts of animals recelving MO-911 showed elther slight decreases or moderate increases. Welght decline also occurred in the hyperthyrold groups; this was isst marked in those animals also receiving a MAO inhibitor (Figure 2). Untroated animals maintained on the control diet showed normal weight gains. 
Sporadic inciderice of diarrite was comon to all the enzyme inhibitor trested rodents and wa particularly prevalent in those andials receiving aeciccoted thyroido The feces of naO inibitor treatod arimal were corted with considerable intestinal mucus. With iproniazid therapy, gross observations of urine samples showed considerabie hemolobin; blood specimens used for jlucose determinations contained laked erythrocytes. Redaish colored ocular discharges, resembing dried blood, were also regularly apparent with iproniazid, but they were present less frequentIy with No-911. An abnormal degree of salivation occurred with both iproniazid and $10-911$ treatments in the euthyroid and hypertbyroid animals, but it appeamed nore prevalent in those individuals treated with the latter compound.

Subacute Toxic1ty. Symptoms of iproniazid toxicity rapidly developed. A number of eithyroid rodents given the $250 \mathrm{mE} / \mathrm{kg}$ dose of Iproniazid died on the second day of injection and all died within 8 days (Table 1 ); concurrent administration of thyroid to a similar croup produced expiration within the 21 day study period whereas conconitant thyroid feeding and iproniazid treatment resulted in all deaths within 6 drys. Although no deaths followed thyroid feeding (group V), or MO-9II administration (groups III and IV), a combination of these substances caused all animals to die within 15 days (groups VIII and IX)。

Tissue Pathology. Livers removed from 21 day, iproniazid treated animals displayed small lesions; kidneys appeared dark 
$r$ whll apleons of all the subjects vesp almost black. Histologic examination of these or ans aled hepatocellular damage, =nal tubule necrosis, and con a able erythrocyte fragmentation in the spleen. Rodents sacrificed after 21 days of MO-911 medication exhibited none of these organic changes, although several of the spleens appeared dark red in color. Thyrold and Mo-912 tissues were unable to te procured.

Eitti11c Blood Pressure and Blood Glucose. Blood pressure and blood glucose doterminations are plotted in Plgures 3 to 8. Standard deviations were derived from $t_{1} s$ formulae:

$$
\frac{Y=E Y}{n} ; \quad \|^{2}=\frac{E(Y-Y)^{2}}{n-I}
$$

where $Y$ represents the individual reading, $Y$ the sample moan, $n$ the samplo number, $s^{2}$ the varlance, and $s$ the standard devlation with n-I degrees of freedom (Ostie, 1958). A

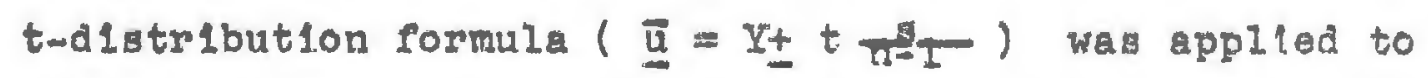
the normal mean blood pressure and glucose lavels of the sixty samples employed using a $t$ value of 2.660 (Dixon and

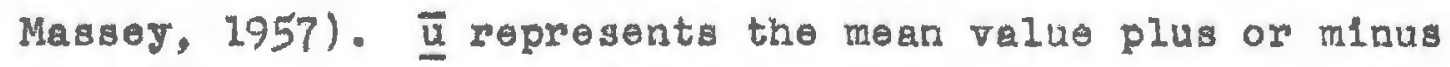
the resultant deviation within $99 \%$ confldence limits with 59 degrees of freedom. The calculated normal, mean blood pressure and glucose levels were determined as $120 \pm 2.65$ $\operatorname{mm} \mathrm{Hg}$ and $104 \pm 3.87 \mathrm{mg} \%$ respectively. The standard blood pressure deviation of the 60 samples was calculated to be $\pm 7.66 \mathrm{~mm} \mathrm{Hg}$ and is represented in the Plgures by the 
soli., horizontal lines. The glucose mean standard deviation was calculated to be \pm 11.20 mg o and is represented by the dashed lines. All readings, inclusive if the preater percentage of their individual standard deviations, when present outside of these areas, are noted as statistically slgniflcant changes.

Three week dally treatment with elther enzyme inhibitor and/or deslecated thyrold eliclted no signiflcant changes in blood glueose lovela, and only in those animals near death did the conoentrations fall (Figures, to 8).

Blood pressures were devate by both thyrold and IAO Inhibltor treatments. Elevations in mean arterlal pressure were witnessed with thyrold fter 48 hours of reoding, rose to poak levals by the sixteonth day. with a plateau occurring at approximately $157 \mathrm{~mm}$ Hg. Blood pressures of eltuyro1d subjects after 48 hours of 1pronlazld (175 mg/kg) med10ation produced algnifleant elevations, followod by a sharp lncreaso to a poak roading of about $165 \mathrm{~mm}$ Hg within 5 days. Preasures romelned atable until the olghth day whon they fell preolpitously below normal; readjustment to normal values occurred by the thirteenth day (Flgure 4) even with continued daliy medioation.

A simliar blood pressure pattern was oxhiblted in MO-911 troated outhyroid rata. In contrast to 1proniaz1a, MO-911 treatment produced an inftial transient hypotensive effect lasting 3 to 4 days. This hypotensive pattern appeared similar at both dose levels, but was of shorter duration at 
the $10 \mathrm{mg} / \mathrm{kg}$ dose. Within 7 to 8 days of all1y $10-911$ treatment blood pressures of both dused roups rose to approximately $155 \mathrm{~mm}$ Iig. This marked hypertenive state, as with iproniazid treated subjects. persisted for several days. The post-hypertensive pressures with MO-9II, however, aid not fall below normotensive levels but stablilzed slightly above the mean normal pressures (Figures 5 and 6 ).

Treatment of hyperthyroid animals ( 3 day thyroid feeding) with MO- 911 produced a marked hypertensive response after 2 days of drug administration, with higher peak systolic pressures prevalingtian during enayte inhlbitor or thyrold acminlstration alone (igures 7 and 8). Blood pressure levels feli erratically anter the oleventh day of treatment, and all anfmals explred either on the fourteenth or fifteenth day.

Urinary Analyses. Urinary dopamine values appeared to be within normal values in rodents made hyperthyroid by the 21 day feeding of $2 \%$ desiccated thyr id (Table 2 ). To the contrary, however, these values were seemiroly elevated in hypertensive, euthyroid animals treated with daily doses of iproniazid $(175 \mathrm{mg} / \mathrm{kg})$. An extremely high value was observed at day 15 where peculiarly enough the blood pressure values were within normal limits (Eigures 3 and 4 ). ACUTE TOKICITY STUDIES

The acute toxicity results are presented in Table 3. Because a perfect statistical analysis of the respective LD $50^{\circ} \mathrm{s}$ was not possible, due to the limited number of animals 
employed and the one eroup aberrantly rezponding to 110.911 at $175 \mathrm{mg} / \mathrm{kg}$, only an approximation to his dose for the enzyme inhibitor in the euthyroid animals could be made; this value was found to be $183.5 \pm 15.0$ (S.E.) $\mathrm{mg} / \mathrm{kg}$ by using a graphic method of analysis (De Beer, 1945). It should be noted that In the thyro1d-MO-911 treated group all deaths, save one at the $152.4 \mathrm{mg} / \mathrm{kg}$ level, occurred within 2 hours. These results show rather conclusively that the intraperitoneal toxicity of MO-911 in hyperthyro1d rats 1s markediy incroased and that the ID 50 of the arug 1108 well below $152 \mathrm{mg} / \mathrm{kg}$ under these clrcumstances. 
TABLE 1

Results of subacute toxicity experiments with iproniazld and M0-911 administered dally

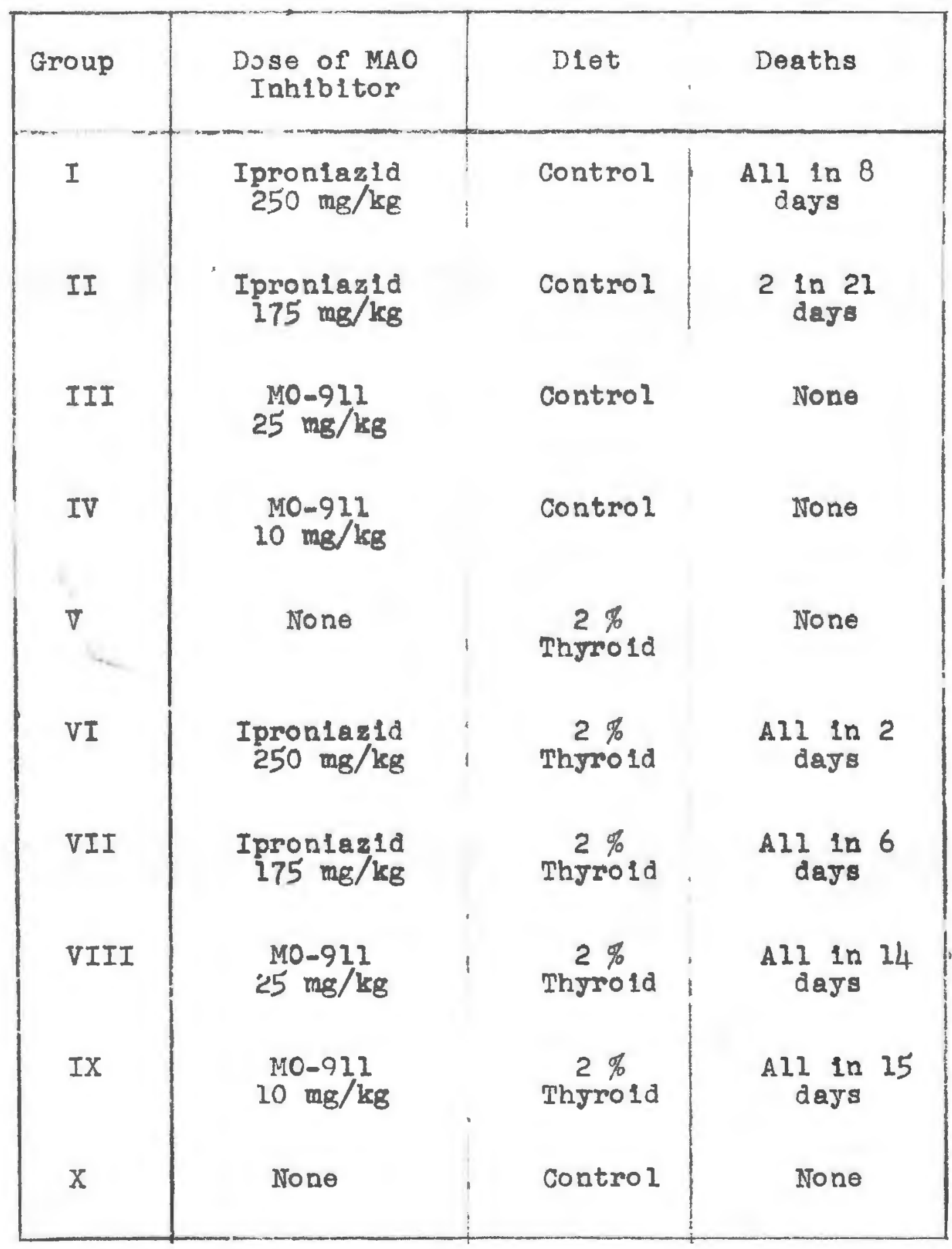


TABLE 2

Orinary dopamine levels of Iproniazid and thyrold treated albino rats

\begin{tabular}{|c|c|c|c|}
\hline Group , & $\begin{array}{l}\text { Day of } \\
\text { collectlon }\end{array}$ & $\begin{array}{l}\text { Urinary } \\
\text { Dopamine } \\
\text { Concentration } \\
\text { (ug/ } / 2)\end{array}$ & $\begin{array}{c}\text { Mean } \\
\text { Arterlal } \\
\text { Blood } \\
\text { Pressure } \\
\text { Hg } \pm \text { S.D. }\end{array}$ \\
\hline \multirow{2}{*}{ Control } & 8 & 362 & $110 \pm 8.5$ \\
\hline & 15 & 475 & $112 \pm 7.9$ \\
\hline \multirow{2}{*}{$\begin{array}{l}\text { Da11y 1.p. } \\
\text { Ipron1azid } \\
175 \mathrm{mg} / \mathrm{kg} \\
\text { Control Diet }\end{array}$} & 8 & 835 & $164 \pm 13.8$ \\
\hline & 15 & 2159 & $116 \pm 27.0$ \\
\hline \multirow{2}{*}{$\underset{\text { Thyrod }}{\text { The }}$} & 8 & 482 & $140 \pm 9.0$ \\
\hline & 15 & 517 & $161 \pm 5.0$ \\
\hline
\end{tabular}


TABLE 3

Acute toxicity of intraperitoneally administered MO-911

\begin{tabular}{|c|c|c|c|c|c|}
\hline Treatment & $\begin{array}{l}\text { Initial } \\
\text { Mean } \\
\text { Wolght } \\
(\mathrm{g})\end{array}$ & \begin{tabular}{c|} 
Mean \\
felght \\
at \\
Injection \\
$(g)$
\end{tabular} & $\begin{array}{l}\text { Dose } \\
(\mathrm{mg} / \mathrm{kg})\end{array}$ & $\begin{array}{l}\text { Response } \\
\text { ( } 12 \mathrm{hrs} \text { ) }\end{array}$ & $\%$ Dead \\
\hline $\begin{array}{l}\text { MO-911, } \\
1 . p .\end{array}$ & $\begin{array}{l}165 \\
160 \\
156 \\
153\end{array}$ & $\begin{array}{l}185 \\
180 \\
163 \\
161\end{array}$ & $\begin{array}{l}187.5 \\
175.0 \\
163.0 \\
152.4\end{array}$ & $\begin{array}{l}4 / 8 \\
2 / 8 \\
3 / 8 \\
2 / 8\end{array}$ & $\begin{array}{l}50.0 \\
25.0 \\
37.5 \\
25.0\end{array}$ \\
\hline $\begin{array}{c}\text { MO-911, } \\
1 . p . \\
+ \text { Throld } \\
(2 \%) \text { Diet }\end{array}$ & $\begin{array}{l}153 \\
154 \\
147 \\
151\end{array}$ & $\begin{array}{l}122 \\
129 \\
127 \\
129\end{array}$ & $\begin{array}{l}187.5 \\
175.0 \\
163.0 \\
152.4\end{array}$ & $\begin{array}{l}8 / 8 \\
8 / 8 \\
8 / 8 \\
8 / 8\end{array}$ & $\begin{array}{l}100.04 \\
100.04 \\
100.04 \\
00.0\end{array}$ \\
\hline $\begin{array}{l}\text { Thyrold } \\
\text { Diet } \\
\text { Controls } \\
+0.14 \mathrm{ml} \\
\text { Normal } \\
\text { Saline } \\
\text { 1.P. }\end{array}$ & 253 & 130 & -- & $0 / 9$ & 0 \\
\hline
\end{tabular}

* All deaths within $2 \mathrm{hr}$ of dosing. 


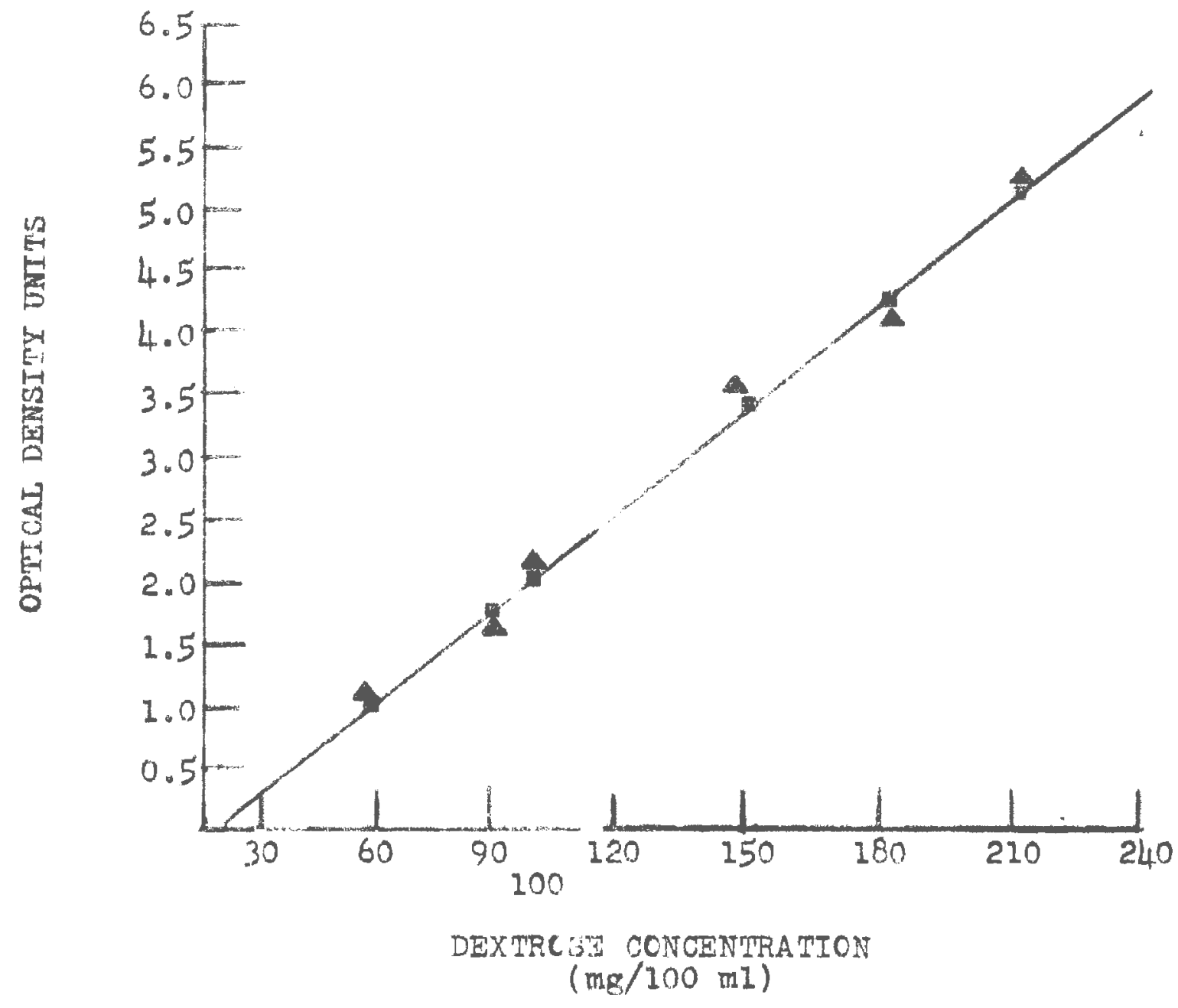

Flg. 1. Blood gluooso standardization curve. Mean Instrument values ; mean calculated values. 


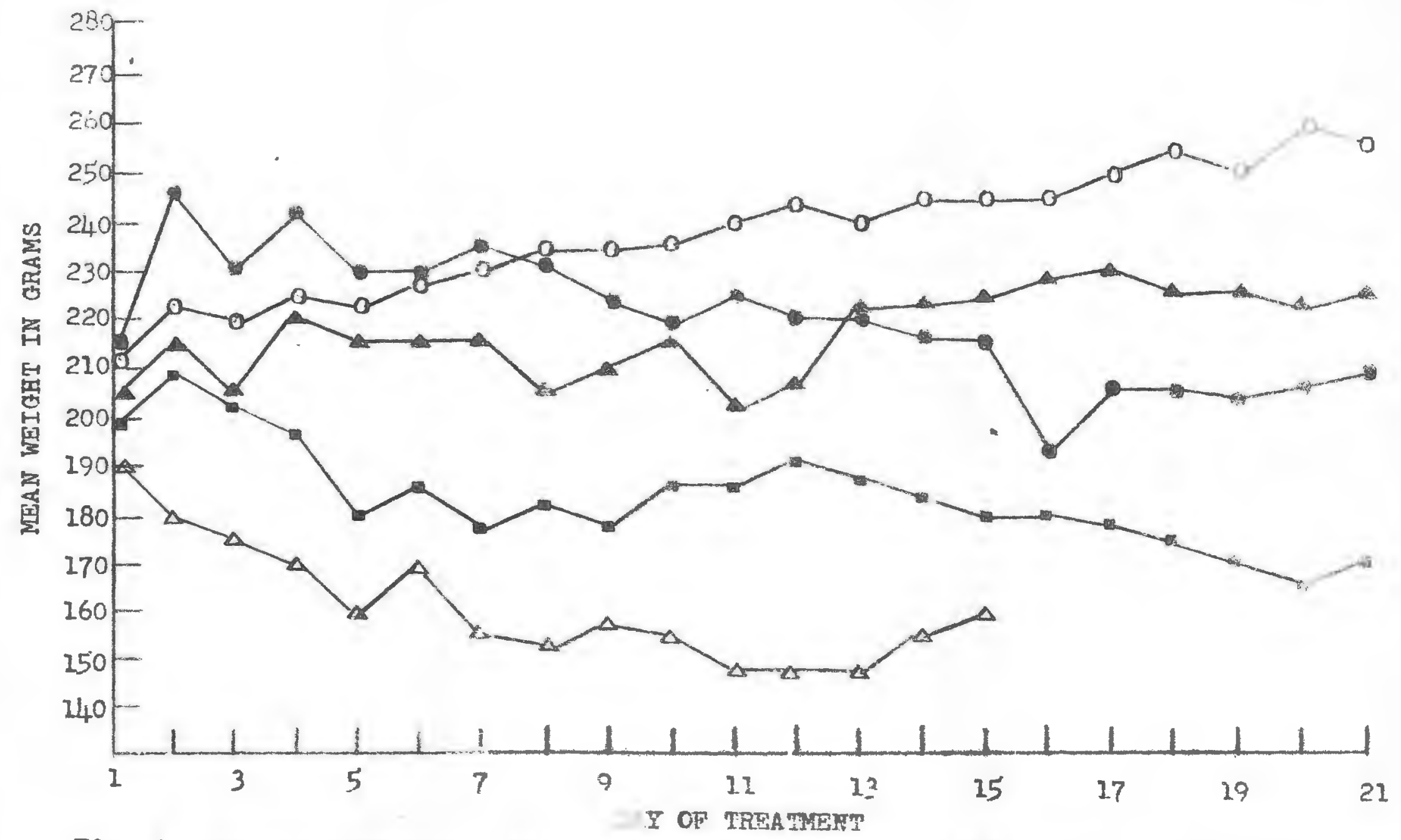

$\ddot{v}$

F1g. 2. Graph of wean body welght $=$ anges 0 . rats under MAO and/or thyrold medication.

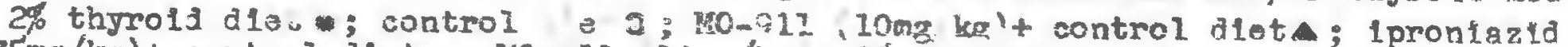
$(175 \mathrm{mg} / \mathrm{kg})+$ control diet +; $\mathrm{KC}-11$ i $\mathrm{mg} / \mathrm{kg}+2 \%$ thyrold 2 lot $\Delta$. 


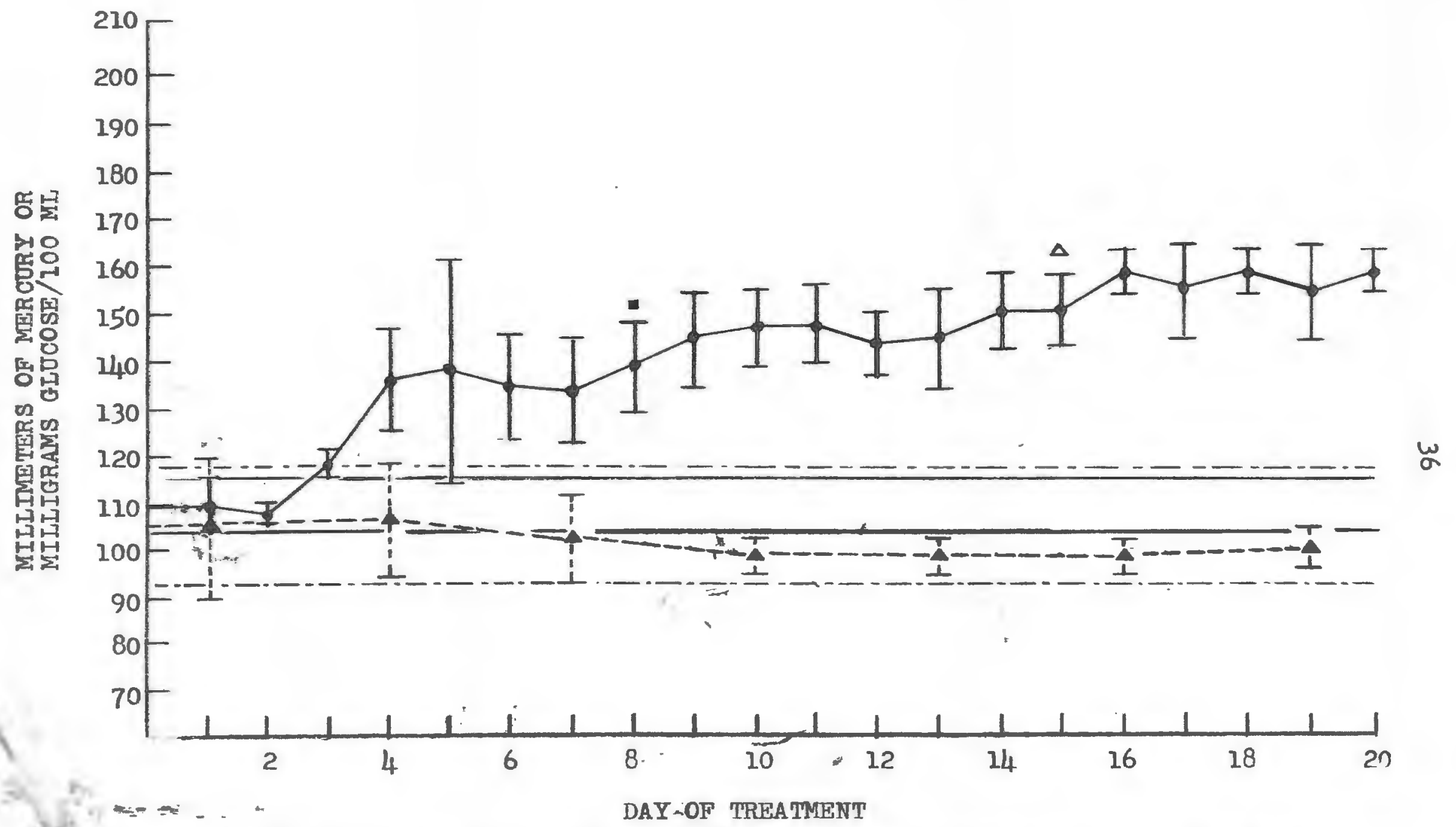

Fig. 3. Blood pressure, blood glucose, and urinary dopamine levels of rats fed $2 \%$ thy rold.

Blood pressure 0 ; blood glucose $\Delta=482$ ug/11ter urinary dopamine; $\Delta=517$ up/11ter urinary dopamine. 


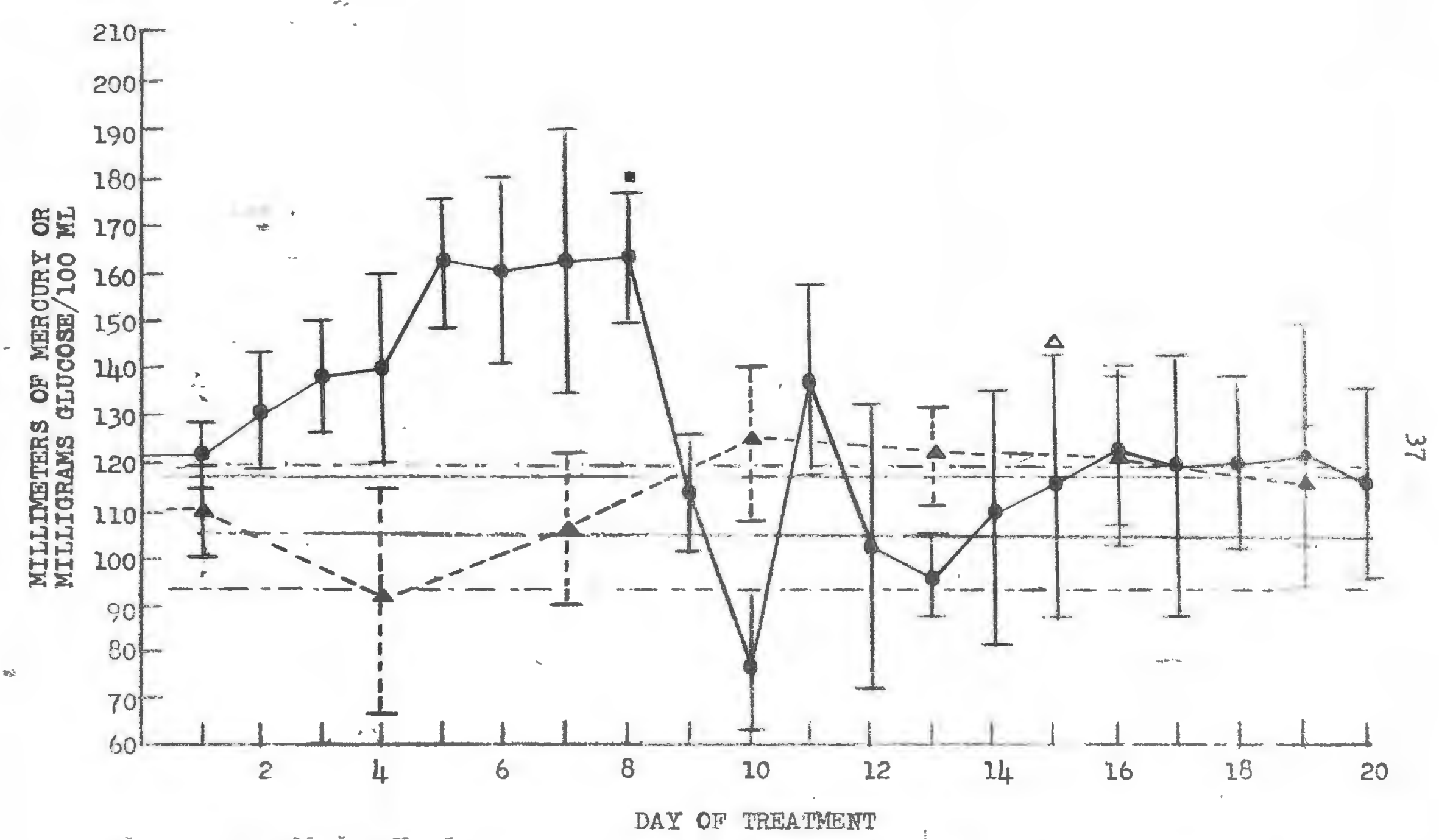

Flg. 4. - Efféct of daliy intraperitoneal doses of ipronlazid ( $175 \mathrm{mg} / \mathrm{kg}$ ) on rat blood pressure, blood glucose, and urinary dopamine levels.

Blood pressure ; blood glucose ; $=835 \mathrm{ug} / 11$ ter urlnary dopamine; $\Delta=2159 \mathrm{ug} / 21 \mathrm{ter}$ urlnary dopamine. 


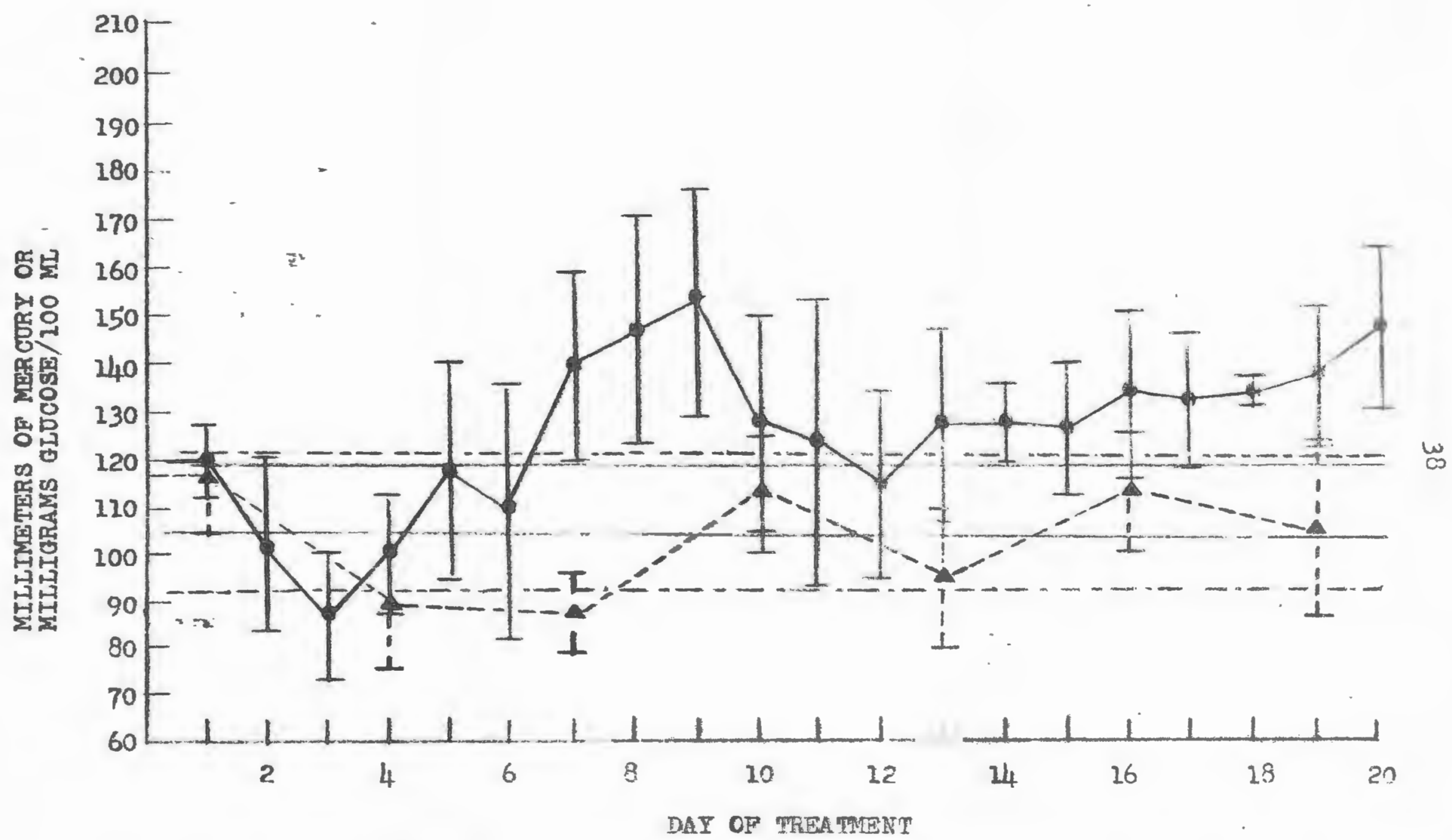

Fig: 5. Effoct of dally intraperitoneal doses of MC-9ll (25mg/kg) on rat biood pressure and blood glucose levels.

Blood pressixe ; blood glucose 4 . 


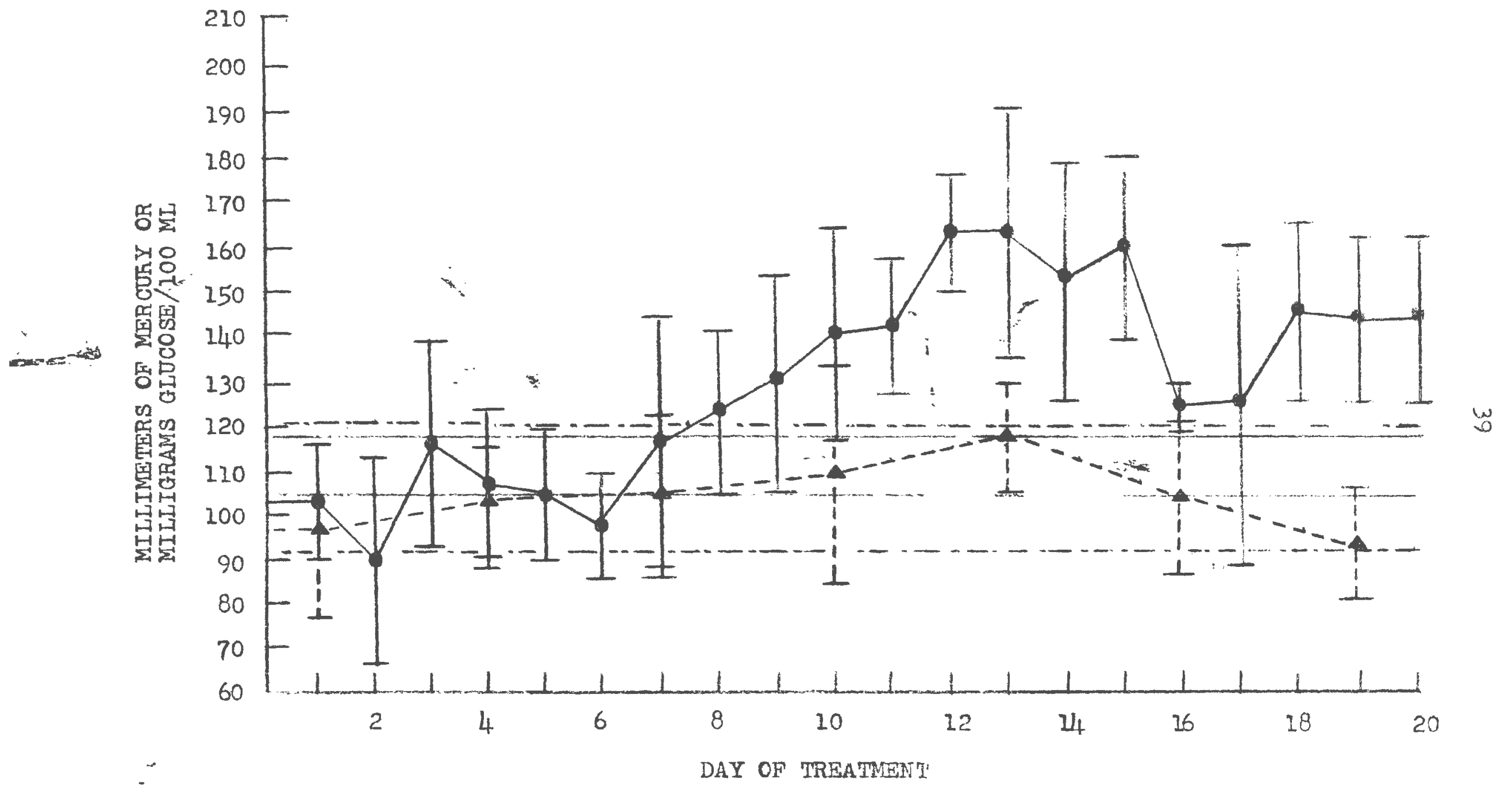

Fig. 6. Effect of dally intraperitoneal doses of MO-9II (10mg/kg) on rat blood pressure and blood glucose levels.

Blood pressure ; blood glucoseA. 


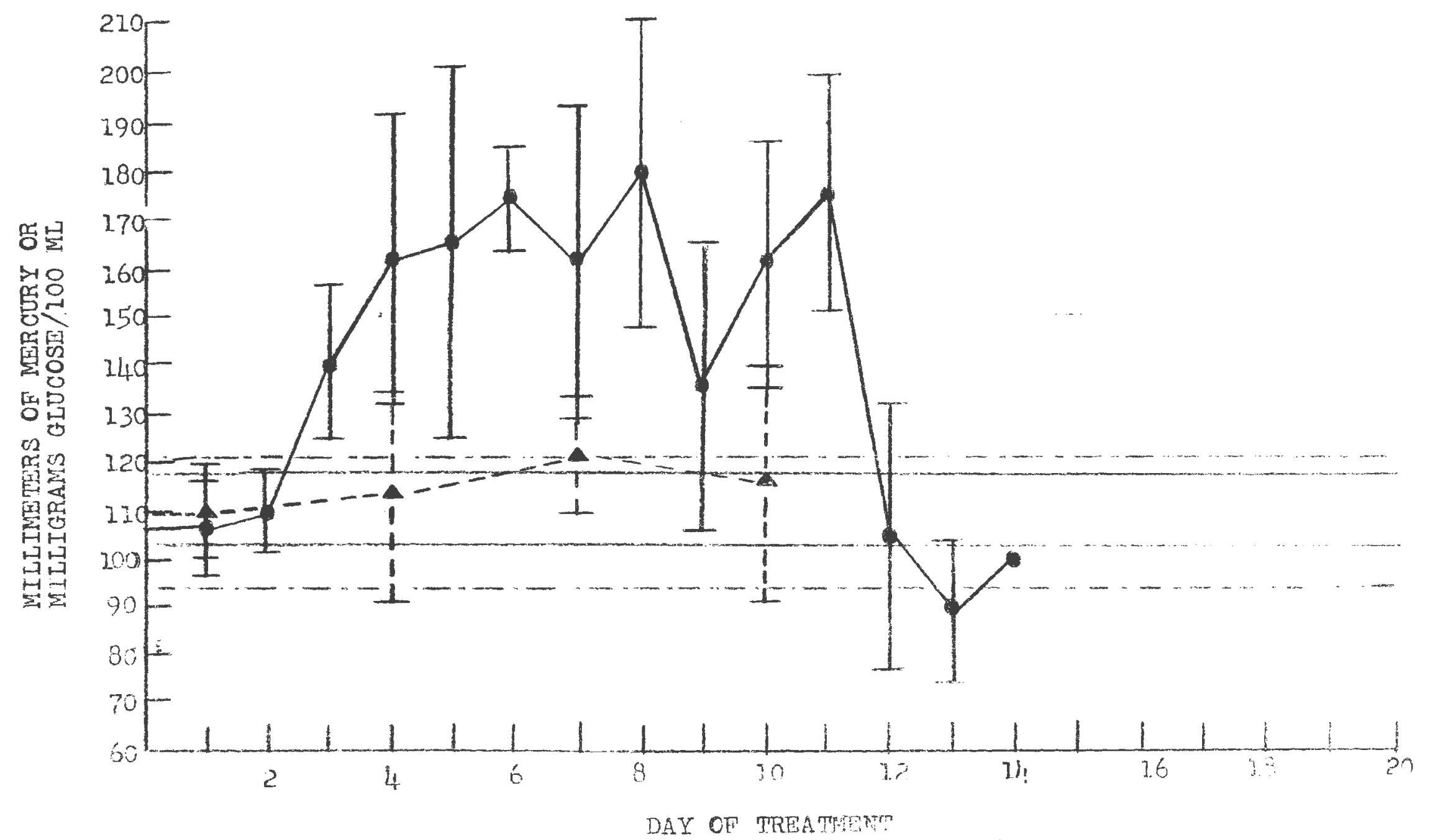

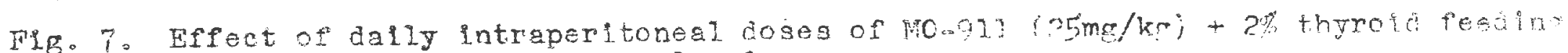
on rat blood pressure and blood glucose levels.
Elood pressure i blood elucose.. 


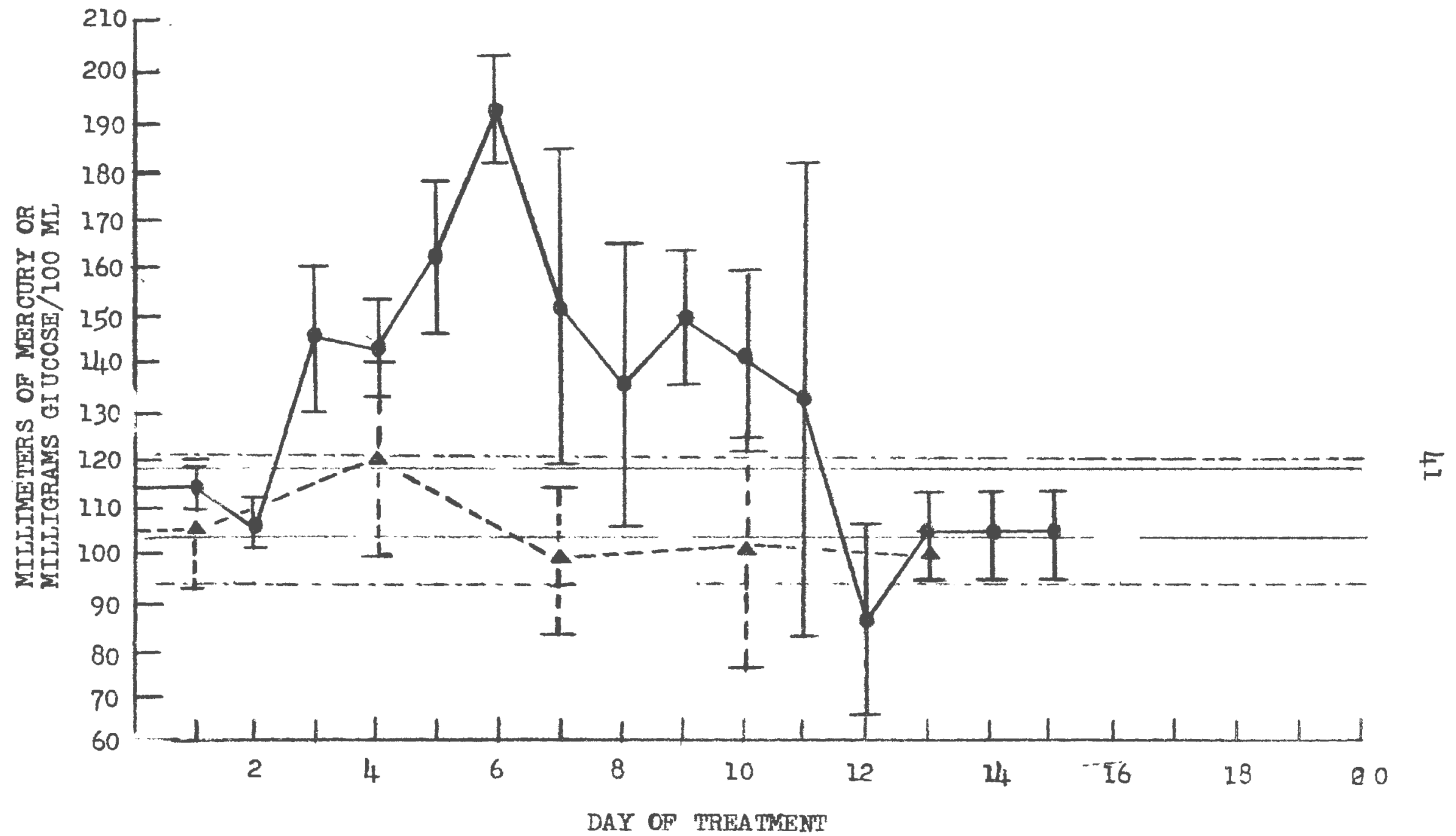

Fig. 8. Effect of dally intraperitoneal doses of $\mathrm{MO}-911(10 \mathrm{mg} / \mathrm{kg})+2 \%$ thyrold feeding on rat blood pr̈essure and blood glucose levels.

Blood pressure; blood glucose 4 . 


\section{DISCUSSION OF RESULTS}

The ostensible reduction of motor activity observed In the MAO inhibitor medicated rodents, at first glance, appears contradictory to the clinical evidence indicating that these compounds are effective psychomotor stimulants (Loomer et 2l., 1957; Tobln et al., 1959; Voelkel, 1959). One must consider, however, the ablitty of these inblbitors to reduce the duration of sleep (KIIne, 1958) and produce Insomnla and weakness (Ayd, 1959; Hawkins et al., 1959; Tobin et 2.1., 1959). Employment of high, subacute doses can thus produce a rapld and profound elevation of central nerrous system activity causing generalized body fatigue; a fatigue condition which would effectively mask its cause.

In the animals where thyroid was combined with enzyme Inhibitor medication, fatigue and weakness were undoubtediy rerlections of apathy. This is a plausible conclusion since hyperthyroldism itself is capable of producing increased central nervous system activity characterized by nervousness and hyperexcltability (Rawson, 1959). Although Dongler et al.., (1956) Indicate that there is no correlation between the degree of anxlety and the rate of thyrold secretion, James (1942) is of the opinion that the level of thyroid activity does a great deal to determine the relative excltability 
of all nervous processes. Again, such gross psychomotor stimulation, incurred through hyporthyroidisms often produces fatigue and general weaknoss (Rawson, 1959). Wang (1927) has actually demonstrated a depression of spontaneous activity in rats after two weeks oral medication with desiccated thyroid which has been attributed to increased fatigue of these animals. An apparent corollary then is that the increased apathy observed in hyperthyroid rodents medicated with MAO Inhibitors may be a result of continuous, immense, potentiated central excitability which brings about a rapid generalized fatigue. Whether or not this potentiated fatigue occurs through a combined effect of thyrold and MAO inhibitors upor amine oxidase systems is an intriguing question.

The apparent increase in food and vater intake of thyrold fed rats, irrespective of their continued welght loss, agrees well with the reports of Carlson (1941) and Barker (1951) but not completely with that of Richter (1933). No doubt the use of vitamins $A$ and $D$ as dietary supplementsoffset, to a degree, certain of the adverse effects of high doses of the thyroid substance. Interestingly, vitamin A has been reported to protect animals against the rise in oxygen consumption caused by desiccated thyrold (Sadu and Brody, 1947).

The welght gains experienced with MO-9ll medicated animals correlates well with clinical observations that MAO inhibitors produce increased appetites resulting in significant welght increases (Tobin et al., 1959). On the other hand, the recullar welght loss observed with iproniazid may be a 
result of the induced toxiclty caused by the high subacute doses employed ( 250 and $175 \mathrm{mg} / \mathrm{kg}$ ). The combination treatment with thyrold and inhibitor, which caused both a drastic welght reduction and loss of appetite, is difficult to interpret, but it cortainly testifies to a potentiation of toxicity.

Toxic manifestations of iproniazid in euthyrold rodents were clearly ovldent as deaths occurred in both the 175 and $250 \mathrm{mg} / \mathrm{kg}$ dose levels durlng the 21 day study. Among. these animals a signiflcant erythrocyte destruction was observor. This is not surprising in as much as bydrazine and its analogues are known to possess hemolytic properties. Benson et al. (1952) have shown that short term ipronlazid administration causes increased destruction and formation erythrooyter. Moreover, hlatological 1nveatigations of animals treated with high dose of hydrazlde lnhibitors often reveal Increased erythrocytos ls as evidenced by hepatio, renal, and splente hemosiderosis, profuse bone marrow collularity, and hyperemla of the apleon (zblnden and Studer, 1959). The lack of gross hemolyt10 changes observed with MO-912 offers added evidence that such toxlcologlcal syndromes are most likely the result of the hydrazine molety of hydrazide MAO inhibitors.

A singular toxicoloelcal observation was the apparent reddish, ocular dischargos whlch occurred with subacute medication with both 1pronlazid and MO-911. Th1s effect has a parallel in the report (Gray, 1961) that ocular discharge of a porphyrin-11ke material occurs in rats under subacute 
medication with etryptamine, a new indole MAO inhibitor.

The feces of MAO inhibitor treated rats were often coated with considerable mucus. This observation parallels the gastrolntestinal hypermucosity noted with the psgohiatric use of similar psychic energlzers (Salnz, 1959); this side effect may reflect irritation of the alimentary canal induced by the medication.

In order to evaluate the possible blood glucose responses of MAO Inhibitors in euthyrold and hyperthyroid rodents, it became necessary to demonstrate the possible effect of both a hydrazide and a nonhydrazlde inhibitor on blood sugar levels, particulariy since Underhill (1911) has stated that subcutaneous injoction of hydrazine sulphate into dogs produces a fall in blood glucose within 24 hours. Also, Underh111 (1911, 1914) reports that this compound when administered to dogs depletes both liver and skeletal gljcogen and prevents glycosuria of depancreatized animals through inhibition of sugar excretion by the kidney. These observations tend to indicate that the hypogljcemic effect seen clinically with iproniazid medication (orconnor et al., 1953; Alexander and Berkeley, 1959; Greenblatt and Kahn, 1959; Welss et al., 1959) could be in part the contribution of the hydrazide molety $(-\mathrm{H}-\mathrm{N}-)$ in this compound. Surprisingly, however, subacute administration of iproniazid and MO-911 to both euthyrold and hyperthyrold rodents evoked no signiflcant blood glucose changes.

of further interest was the lack of signiflcant blood glucose changes resulting from $2 \%$ desiccated thyrold foeding. 
treated rodents.

Although extensive investigation tends to support the hypothesis that iproniazid is not a practical in vivo potentiator of the effects of peripheral $E$ and NE (Cahen et al., 1953; Schayer and Smiley, 1953; Schayer et al., 1953; Balzer and Holtz, 1956; Kamijo et al., 1956; Corne and Graham, 1957; and others), ovidenoe indicates that breakdown of $\mathrm{E}$ and $\mathrm{NE}$ is depreseed in 1proniazid treated rats (Schayer, 1953; Schajer et al., 1955). The regultant perlpheral vasopressor effects of these hormones may, in part, explain the hypertens10n. Goldberg (1959) has reported that phentprazine, a chemlcal analogue of 1pronlazid. caldses a marked pressor offect in anesthetized, vagotomized dogs when given Intravenously.

Rodents fod $2 \%$ lesiccated thyrold presented no such 1noonslstent vascular effects; the hypertension developed rapidiy and was malntained. This confirms the flindings of Samiy (1952) with thyroxine in rats and rabbits. Although hypertension is not normalig reported syndrome in hyperthyroldism, Blumgart et al.(1930) have stated that blood volume increases in this condition. This together with a probable Increase in cardiac outpat can elevate blood pressures during thyrold overactivity. Although it is simple to accept the supposition that elevated cardiac output is primarily a funotion of Inoreased motabolism, Rasmussen (1941) declarea that induced hyperthyroldism results in cardiac changes that cannot be directly oorrelated w1th metabolic rate. In addition, 
Leblond and Hoff (1944) Indicate a possible direct effect of thyroid on the heart. Whether these effects are directly responsibla for elevated blood pressures is difficult to ascerta1n. A noteworthy observation is the fact that when thyroid and inhibitor adinistration are combined in rodents all hypotensive reactions as exhibited with MAO Inhibitor treatment alone are obliterated. Whether such responses are a drect potentiation of combined inhibitor and thrrold treatment requires further invest1gation.

S1noo MAO Inhlb1tors are capablo of Inh1biting a normal oatabol1c pathway of dopamine in vivo (Holtz, 1959), one would expect an increase of this substance in certaln body t1ssuos. After prolonged lnhlb1tor treatment in rodents (14 days) with high, 1ntraperitoneal doses of 1proniazid, a slgniflcant rise in urinary dopamine levels did occur. Dopamine acts as a pressor in the rat (Vogt, 1959), although 1t is decidedy less potent than other catecholemines (Ponnefatber and Rand, 1960). Sam1y (1952) noted that hyperthyroldism in rats augmented the pressor response to Intravenous doses of dingdroxyphenylalanine, the precursor of dopamine; his result inferred that this effect was duo to enhanced receptor sensitivity to the formed dopamine. Although it was not possible to determine urinarg levels of dopamine from MAO 1nhibitor treated, hyperthyrold rats in the prosent experiments, it might very well be that samiy's findings explain, in part, the rapid onset and marked pressor effects reoorded in these troated animals. It 1s difficult, 
on the other hand, to explain the apparent lack of correlation between high urinary dopamine levels and the pressor responses in response to hlgh dally doses of lpronlazld. It may simply be a case of cardiovascular adaptation of the drug treated animal.

The original intention was to administer both fproniazid and MO-911 to both hyper- and euthyrold rats in equimolar concentrations per kllogram of body welght. Since we orlginally employed lpronlazld at 250 and $175 \mathrm{mg} / \mathrm{kg}$ dose levels, this neoessitated the use of equimolar MO-91I concentrations at 175 and $123 \mathrm{mg} / \mathrm{kg}$. In our preliminary observations, the subacute adminlstration of MO-911 at these doses produced total mortality after the second injection. Subsequent information recelved from Abbott Laboratories 17 Indicated that subacute intravenous administration of 25 and $10 \mathrm{mg} / \mathrm{kg}$ of MO-911 was well tolerated in rats. Therefore, these new doses were utlilzed and found to be satisfactory.

of signiflcant interest was the acute and subacute potentiation of MAO inhibitor toxicity in hyperthyrold animals. The administration of desiccated thyrold or thyroxine is known to modify the susceptiblilty of animals to the poisonous offects of a number of substances. Thyrold hormone increases the toxiclty of alloxan (Houssay and Sara, 1945), cocalne (Glaubach and Pick, 1931), morphine (Hunt and Seldell, 1910), dinltrophenol (Glaubach and Plok, 1934), eplnephrine

17 Letter from Dr. G.M. Everett, Abbott Laboratories, Chicago, Illinois. 
(Kroneberg and Huter, 1951; Kroneberg, 1952), and other substances. Large doses of thyrola substance may produce Iiver damage (Barker, 1951), and this finds parallel in the ability of cortala MAO Inhibitors to intensify I1ver damago caused by certaln hepatotoxic agents (zbinden and Studer, 1959). However, the cause of the augmented lethallty with lpronlazld and MO-911 is zot easily understood, but because of the early onset of malalso and rapld demise a drect sensitirity to the toxic offects to the MAO inbibitor molecule per se seems to be the most likely explanation. These effects, on the other hand, may possibly bo related to MAO lahibltion coupled with the similar enzymetio in vivo effects of thyrold feoding (Spinks and Burn, 1952; Z1le and Lardy, 1959) resulting in an acute liberation of unbound catecholamines, a dimlnished ablilty of the animal to copo with stress, and a predisposition to fatal thyrotoxicosis. The reported psychotherapeutic inoompatibility of concurrent MAO Inhlbitor and thyrold modication (Balley et al., 1959; KIine, 1961) may posslbly be explained by this hormone induced sensitivity to drug toxicity. 


\section{SUMMARY AND CONCLUSIONS}

1. The present research was undertaken using blood glucose, blood pressure, and the acute and subaoute toxic1ty studies in rodents a paramoters, to evaluate the possible psychotherapeut10 Incompatibllity which bas been reported to exist with concu rent thyrold and MAO Inhibitor medication.

2. Dally Intraperitoneal infection of ipronlazid or MO-911 for three weeks reduced the sponteneous motor activity of male albino rats. Concomitant foeding of two porcent desiccated thyrold augmented this apathy.

3. The subacute, intraperitoneal administration of elther ipronlazid or MO-91I in high doses causec serer loss of body welght; this welght 10 sas aggravatad by concurrent thyro1d foeding.

4. The slugg1shnes, aggravated welght decline, and symtoms of malalo from combinod thyrold and MAO inhlbitor medication may bo explainod by an increased sensitivity of hyperthyro1d rats to acute or Bubacute MAO inh1bitor toxicity.

5. Limited gross and histologlo observations revealed that hlgh, dally doses of Ipronlaz1d, for three weoks, caused hepatic and renal damage and erythrocyte hemolysis in 
the spleen. MO-912 ir 11 , parenteral dos of ten or twenty-five milifgrams per kilonram did mot produco ang apparent orgenlc chan 3 , although splenic darkening was noted.

6. In the doses employed, the MAO inhlbitors alone or with thyro1d treatment, falled to oliclt ang signifloant changes in blood sugar. Fooding of a two percent thyroid diet for three wooks likewloe falled to modify the blood glucose ploture.

7. The systollo blood presoures of ipronlezid treat d, outhrold animals rose algniflcantiy above normotenalve levela, beginniag after forty-elght hours of medleation. to a peak on the elghth day; whereupon they suddeniy and preclpitously fell to hypotenslve lovels.

8. MO-912, in dally doses of ton or twenty-flve mLlligrams per kilogram body wolght, ollcited an initial and marked fall in blood pressure. This response soon gave way in both instances to a slowly developing hypertension which persisted unt1l the tenth or sixteenth day of treatment.

9. The fooding of thyrold substance to $10-911$ treatod rats obliterated the initial hypotensio and effected a sharp pressor response within threo daye of continued inhlbitor medication. These pressor effects were greater and more acute in onset than those noted with elther M0-911 or thyroid administration.

10. Urinary dopamine levels following na or two week treatment of high, dally parenteral doses of lpronlazid rose about 
three fold. The urinary levels of this biogentc catecholamine could not be correlated with pressor responses.

11. Although admittedly limited in extent, studies of urinary dopamine levels did not reveal any increase after three week feeding of rats with two percent desicceted thyroid.

12. These results suggest strongly that the direct and Indirect pharmacologic actions of iproniazid and MO-911, given in high da1ly doses to rats, are aggravated by a hyperthyrold state; these experimental findings have obvious clinical significance. 
LIST OF REFERENCES

Aeb1, Ho: Helv. physiol. acta 10: 43, 1952.

Albert, A.: Ann. N.Y. Acad. Sc1. 50: 466, 1949.

Albright, E. C., Larson, F。 Co, Tomita, Ko and Lardy, H. A.: Endocrinology 59: 252, 1956.

Alexander, $I_{0}$ and Berkeley, A. W. Ann. N. Y. Acad. Sc1. 80: $669,1959$.

Anderson, $R_{0} C_{0}$, Henderson, $F_{0} Q_{0}$ and Chen, $K_{0} K_{0}: J_{0}$ Amer. pharm. Ass., Sc1. Ed. 32: 204-208, 1943.

Armstrong, M. D., Shaw, K, N, F, and Wall, $P_{0} E_{0}: J . b 101$. Chom. 218: 293, 1956.

Axelrod, J.: Sclence 126: 400, 1957.

Ayd, F. J. Ann. N. Y. Acad. Sc1. 80:734, 1959.

Balley, S. DiA., Buce1, L., Gosoline, E., Kilne, N., Fark, I. H., Rochlin, D。, Saunders, J. and Varab

Ann. $\mathbf{H}_{\text {. }}$. Acad. Sc1. 80: $652,1959$. Balzer, H. and Holtz, P.: Areh. exp. Path. Pharmak. 227:51.7,

Barker, S. B.: Phjo101. Rev. 21: 205, 1951.

Barker, S. B.: C1ba symp. 12: 253, 1957.

Barker, S. B.: Endocrinology 59: $548 ; 1958$.

Benson, J. M., Sterko, P. I. and Roe, M. D.: Amer. Rer. Tuberc. 65: 376,1952 .

Bortler, A., Carlsson, A, and Rosengren, E. Acta physiol. scand. $44: 273,1958$.

Bortrand, J., Dolay, J. and Gullilan, J.: C. R. Soc. Blol., Par1s 129: $395,1938$.

Elaschko, H.: Pharmaco1. Rev. 2: 307, 1959. 
Elaschko, Ho, Richter, D。and Soblossmann, Ho: Jo Physiol. $20: 1,1937$.

Blascbko, Ho, Richter, D, and Schlossmant, H.: ibid., I I $60,1940$.

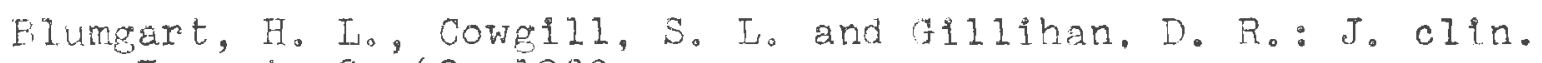
Invest. $9: 60,1332$.

Bowman, K.: Arch. Neurol. Psychlat., Chicago 14: 819. 1225.

Brodie, Bo, Spector, S. and Shore. P.: Ann. N. Y. Acad. Sc1. 80: $60 \%, 195 \%$.

Brody, E. B.: Endocrinology 29: 916, 1941a.

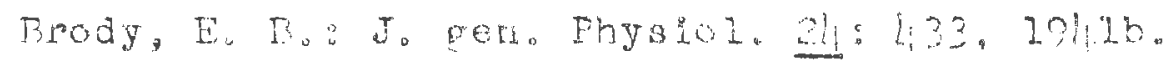

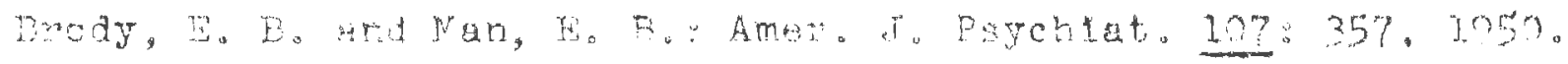

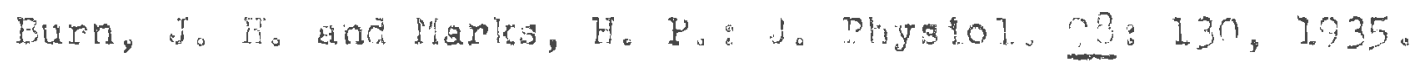

Eurn, To $\mathrm{A}_{\mathrm{a}}$ and Splnks, A.: 1b1d., 126: 46, 1752.

Caken, R. To, Tilas, A. W. and Parlati, P.J.: Fod. Proc. 12: $\because 77,1953$.

Carison, W. S.: Jo comp. Fsychol. $32: 45,1941$.

Carlsson, A. and Waldeck, B.: Acta physlol. scand. 44: 293, 1959 .

Carsten, M。 and Wynston, L。 K。: Ann. M.Y.Acad. Sc1. 86: $612,1960$.

Cesarman, T.: Arch. Inst. Cardiol. MÉx, 27:563, 1057.

Cesarman, To: Jo clin. exp。Psychopath. Qusrt. Rev. Psychiat. Neurol. 19: Suppl., 169, 1959.

Cesarman, To: Ann. No Y Acad. Sci. 80: 283, 125?.

Clarke, W. Go: Pharmacol. Rev. 11:330, 1959.

Coggesha11, H. Co and Greene, J. A.: Amer. J. Physiol. 105: $103,1933$.

Corne, So Jo ard Graham, Jo Po: J. Phys1ol. 135: 339, 1?57.

Cossio, Po: Ann, H. Y. Aczd. Sol, 80:1009, 1957.

Cotzlas, G。 Co and Dole, V.P.: Proc. Socoexp.Elol。, N. Y. 18: 157, 1951. 
Crane, G. E。: J. nerv. ment. D1s. 124: $322,1956$.

Cranswlck, E.: Amer. J. Psychlat. 107: 357, 1955.

Crawford, T. and Law, W.: J. Pharm., Lond.10: 179, 1958.

Da Costa, F. M. and Goldberg, L。I.: Fed. Proc, 20: 318, 1961.

Delay, J. and Bulsson, J.: J. clin. exp. Psychopath. Quart. Rer. Psychlat. Nourol. 19: Suppl., 1, 1958.

Dixon, W. Jo and Massey, F. J.: Introduction to Statistical Analysis, 2nd od., MeGraw H1ll Book Co., Inc. N. Y., 1957.

Dongler, M., Wittkower, E. D. Stephens-Newsham, L., Hor fmann, M. M.: Pajohosom. Med. 18: 310, 1956.

Drabkin, D. L.: J. b101. Chem. 182: 335, 1950a.

Drabkin, D. I。: 1bld., 182: 351, 2950 b.

Dubnick, B., Leeson, G. and Leverett, Ro: The Pharmacologlat 2: 67,1960 .

Dunlap, H. F. and Moersch, F. P.: Amer. J. Psychiat. 92: 1225, 1935.

Etling, N. and Barker, S. B.: Endocr1nology 64: 753, 1959.

Flach, F., Cellan, C. and Rawson, R.: Amer. J. Psychlat. 114: $841,1958$.

Flach, F., Stokes, P., Llang, E., Dlethelm, O. and Rawson, R.: Ann. N. Y. Acad. So1. 86: 582, 1960.

Fullerton, C. W. and Harrop, C. A.: Johns Hopk. Hosp. Bull. 46: 203,2930 .

Gerle1, F.: Endokr1nolog10 19:387, 1938. Quoted by Sp1nks, A.: J. Phys101. 117: 35, 1952.

Gertner, S. B.: Nature 183: 750, 1959.

Gojolin, H. R.: Arch. Intern. Med. 16: 975, 1915.

Geyer, H.: J. o11n. exp. Psychopath. Quart. Rev. Phychlat. Nouro 1. 19: supp1., 86, 1958.

Glaubach, S. and Plck, E. P.: Arch. exp. Path. Pharmak. 162: $537,1931$.

Glaubach, S. and P10k, E。 P.: Schwo1z. med. Wachr. 29: 649, 1934. 
Goldberg, L。 I.: Ann. N. Y. Acad. Sc1. 80:639, 1959.

Goolden, A. W。 G。: Lancet 270: 890, 1956.

Grave, $R_{0} J_{0}:$ Iondon med, surg. Jo part II: 1835. Quoted by Rawson, R. and Sonenberg, M。 Diseases of Metabollsm, 4th ed., W. B. Saunders, Phliadelphia, 1959. Gravenstein, Jo So and Thier, M。 D。: The Pharmacologist 2:
65,1960 .

Gray, J. E.: J. Neuropsyohlat. 2; 5163, 1961.

Groonblatt, I. J. and Kahn, A.: Ann. No Y. Acad, Sc1. 80: 947, 1959.

Groer, M. A.: Clba Symp. 10: 72, 1957.

Groer $M_{0} A_{0}$, Yamada, $T_{0}$ and IIno, S.: Ann. N. Y. Acad. So1. 86: $667,1960$.

Gross, J. and Loblond, P.: Proc, Soc. exp. B1ol., N. Y. 76: 686,1951 .

Gross, J. and P1tt-RIvers, R.: Lancot 261: 766, 1951.

Gross, J. and P1tt-R1vers, R.: 1b1d., 262: 439, 1952a.

Aross, J. and P1tt-R1vers, R.: 1b1d., 262: 539, $1952 \mathrm{~b}$.

Gross, J. and P1tt-Rivers, R.: B10chom. J. 53; 645, 19;3.

Gross, J. and Pltt-RIvers, R.: Recent Progr. Formone Ros. 10: $109,1954$.

Hague, $M_{.} E_{0}, L 11110, R . J .$, Scharfner, C. S, and Brlggs, P.: Endocrlnology 42: $273,1948$.

Harnes, J.: J. clln. exp. Psychopath. Quart. Rov. Psychlat. Neuro 1. 19: Supp1., 152, 1958.

Harington, C. R.: Blochem. J. 20: 293, 1926.

Harlington, C. R.: Proo. roy. Soc. 232: 223, 1944.

Harr1s, G. Wo and Woods, J. W.: Clba Symp. 10: 21, 1957.

Hawkins, J.: Blochem. J. 50: 577, 1952.

Hawkins, R。 J., Hillorad, W. E. Moulton, J. H., and Fabing, H.: Ann. N. Y. Acad. Sc1. 80: 745. 1959.

Hertz, S. and Evans, R.D.: Endocrinology 29: 82, 1941. 
Hoch, F. Lo and Lipmann, F.: Fod. Proc. 12: 218, 1953.

Holtz, P.: Pharmacol. Rev。 11: 317, 1959. Hoskins, $R_{0}$. G.: The Blology of Schlzophrenia, Norton, No $Y_{0}$,
1946.

Houssay, B. A. and Sara, J. G.: Rer. Soc. argent. Blol. 21: 81,1945 .

Hunt, R. and Seldell, A.: J. Pharmacol. 2: 15, 1910.

Ingbar, S.: Ann. N. Y. Aoad. Sc1. 86: $440,1960$.

Jamos, W. F.: Amer. anat. Mom. 19: 525, 1941.

Jamleson, G. R. and Wall, J. R.: Psjchlat. Quart. 10: 464, 1936.

Kamljo, K., Koolle, J. B. and Wagner, H. H.: J. Pharmecol. 117: $213,1956$.

Kendal1, E. C.: Trans. Ass. Amer. Physens 30: 420, 1915a.

Kendal1, E. C.: 1b1d., 31: 134, 1915b.

Kendall, E. C.: J. b101. Chem. 20: 501, 19150.

Kersten, H., Brosene, W. G., Ablonde, F. and Subba Row:

J. Lab. clln. Med. 32: 1090, 1947.

Klemperer, H. G.: Blochem. J. 60: 122, 1951.

Kline, N. S.: J. elln, exp. Pejchopath. Quart. Rev. Pajchlat. Nouro 1. 19: Suppi., 72, 1958.

Kline, N. S.: J. Neuropsychiat. 2: 525, 1961.

Kroneber8, a.: Arch. exp. Path. Pharmak, 216: 240, 2952.

Kroneberg, G. and Huter, F.: K11n. Wschr. 29: 649, 1951.

Lardy, H. A.: Hormonal Regulation of Energy Motabollam, p. 4582, Charies C. Thomas Co.. Springf101d, Illino 1a, 1957.

Lardy, H. A. and Maley, G. F.: Recent Progr. Hormone Res. 10: 129,1954 .

LardJ, H. A., Tomita, K., Larson, F. and Albright, E.: C1ba Symp. 10: 129, 1954.

Leblond, C. P. and Grad, B.: J. Pharmacol. 94: 125, 1948.

Leblond, C. P. and Hofr, H. E.: Amer. J. Physlol. 141: 32, 1944. 


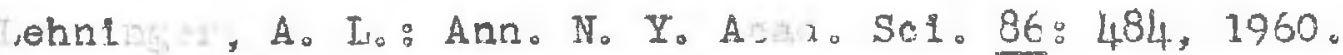

Llssityk, S. and Bouchllloux, C Clba Symp. 10: 135, 1757.

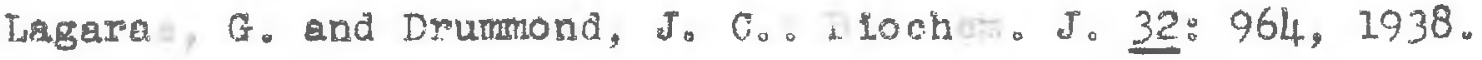

Loomer, $\mathrm{II}_{\circ} \mathrm{P}_{0}$, Saunders, Jo $\mathrm{C}_{0}$ and Kl1ne, No So: Psychlat. Resoarch Hopts。 8: 129, 1957.

Lozner, E. R。, WInkler, A. Wo, Taylor, F。 Ho and Petars, Jo: J. clin. Invest. 20: 507, 1941.

Major, R. H.: Classic Description of Diseases, 2nd od., Charlos C. Thomas, Springfleld, 1939.

Martius, C. and Hess, B.: Arch. 1310chem. Blophys. 33:486, 1351.

Martius, C. and Hess, B.: Arch. Axp. Path. Pharmak. 216:45. 1952 .

Masters, A. and Donoso, E. Ann. N. Y. Acad. Se1. 80: 1020, 1959.

Mirsky, I. Ao and Broh-Kahn, R. Ho: Amer. J. Phys101. 117:

Myers, J. D., Brannon, E. S. and Holland, B. C.: J. clin. Invest. 29: 1069, 1950 .

Nelson, N.: Jo b101. Chem. 153: 375, 1944.

Nelson, $S_{0}$ and Bradley, $T_{0}$ R。: Ann。No $R_{0}$ Acad. Sc1. 86: 647, 1960.

Nlemeyer, H., Crane, R. K., Rennedy, E. Po and Llpmann, F.: Fed. Proc. 10: 229, 1951.

0s Connor, J. B., Howlett, K. S., Jr., and Wagner, R. R.: Amer. Rev. Tuberc. 68: 270, 1953.

Ostlo, B.: Statistics in Research, Iowa Stato College Press, Ames, Iowa, 1958.

Ozak1, M., Welssbach, H., Ozakl, A.. Witkop, B. and toderfiend, S.: J. med. pharm. Cham. 2: $591,1960$.

Parry, $C_{0} H_{0}:$ Colloctlons from the Unpublished Medical Writings of Dr. C. H. Parry, London 2: 111, 1925. Quoted by Rawson, R. and Sonenberg, M.: Diserases of Metabolism. 4th ed., W. B. Saunders, Philadelphla, 1959.

Pennefather, Jo N. and Rand, M, J, : Jo Phys101. 154: 277, 1960. 
Pletcher, A.: Schwe1z. med. Wschr. 87: 1532, 1957.

Pletcher, A. and Pellmont, B.: J. clin. exp. Psychopath. Quart. Rev. Psychlat. Neurol. 19: Suppl., 163, 1958.

Pltt-Rivers, R.: Ann. No Y。 Acad. Sc1. 86: 362, 1960.

Pltt-Rivers, R., Stanbury, J. B.: J. clin. Endocrin. 15: $616,1955$.

Raab, W.: J. Amer. med. Ass. 128: 249, 1945.

Randall, I.: J. clin. exp. Psychopath. Quart. Rev. Psychlat. Neurol. 19: Suppl., 178, 1958.

Rasmussen, H.: Acta mod. scand. 115: 1, 1941.

Rawson, R. W.: Ann. N. Y. Acad. Sc1. 50: 491, 1949.

Rawson, R. W. and Sonenberg, M.: Diseases of Metabolism, 4th ed., W. B. Saunders, Ph1ladelph1a, 1959.

Resalck, O.: Ann. N. Y. Acad. Sc1. 80: 726, 1959.

Rlohter, D. and Tingey, A. H.: J. Phys101. 97: 265, 1939.

Roche, J. and Michel, R.: Physiol Rev. 35: 583, 1955.

Roche, J. and Michel, R.: Ann. No. Y. Acad. So1. 86: 454, 1960.

Roche, J., Mlohel, R. and Jousn, P.: C1ba Symp. 10: 168, 1957.

Ross, D. A. and Schwab, R. S.: Endoorinology 25: 75, 1939.

Sadhu, D.P. and Brody, S.: Amer. J. Phys101. 1149: 400, 1947.

Salnz, A.: Ana. N. Y. Acad. So1. 80: 780, 1959.

Samis, A. E.: Fod.Proc. 11: 136, 1952.

Schayer, R.W.: J. b101. Chem. 203: 787, 1953. Schayer, R. W., Konnedy, J. and Smlley, R. L.: 1b1d., 205:
739, 1953.

Schayer, R. W. and Smiley, R. L.: 1b1d., 202: 425, 1953.

Schajer, R. W., Smiloy, R. I. Dav1s, K. J. and Kobayash1, Y.: Amer. J. Phys101. 182: 285, 1955.

Schelaberg, P., Stead, E., Brannon, E. S. and Warren, J.: J. olin. Invest. 29: $1239,2950$.

Schwelzer, W.: Ann. N. Y. Acad. Sc1. 80: 1016, 1959. 
Selikoff, H. I0, Robitalk, $F_{0} H_{0}$ and Ornsteln, G。 G。: Amer. Rev. Tuberc. 67: 212, 1953.

Sinth, C. I。: J. Endocrin. 19: 205, 1960 .

Smith, D. J.: Amer. J. Phya101. 277: 7, 1954.

Smith, R. H. and W1lliams-Ashman, H. G.: Nature 164: 457, 1949 .

SomogJ1, M.: J. b101. Chem, 160:61, 1945.

Sonenberg, Mo and Money, W.: Ann. N. Y. Acad. Sc1. 86: $625,1960$.

Spector, S. D., Prockrop, P. A., Shore, A. and Brod1e, B.: Sclénce 127: 704, 1958.

Spinks, A.: Jo Phys101. 117: 35, 1952.

Splaks, A. and Burn, J. H.: Brit. J. Pharmacol. I: 93, 1952.

Tapley, D. F., Cooper, C. and Lehninger, A. L。: Acta Blochem. Blophys. 18: 597, 1955.

Taurog, A., Tong, W. and Chaikofr, T. I.: Clba Symp. 10:
72, iǵ5.

Tobin, J. M., Plante, M. A: and Kupsk1, L.: Ann. N. Y. Acad. Sc1. 80: 760, 1959.

Tomita, K., Lardy, H., Larson, F.C. and Albright, E. C.: J. b101. Chem. 224: $387,1957$.

Tipton, S. R, and N1xon, W.: EndocrinologJ 39: 300, 1946. Trotter, W. R.: Lancet 269: 374. 1955.

Udenfrlend, S.: Ann. N. Y. Acad. Sc1. 80: 588, 1959.

Udenfrlend, S., Welssbech, A. and Bogdansk1, D. F.: Ann. N. Y. Acad. Sc1. 66: 602, 1957.

Underh111, F. P.: J. b10I. Chem. 10: 159, 1911.

Underh111, F. P.: 1b1d., 17: 293, 1914.

Underh111, F. P. andे Fine, M. S.: 1b1d., 10: 271, 1911.

Vookel, A.: Ann. N. Y. Acad. Sc1. 80: 680, 1959.

von Basedow, C. A.: Wchnschr. f. d. g1s. He11k. 6: 197, 1840. Quoted by Rarson, $R$. and Sonenberg, $\mathrm{M}_{1}$ : D1seases of Motabol1sm, 4th ed., Wo B. Saunders, Ph1la., 1959. 
Vogt, M。: Pharmacol. Rev. 11: 249, 1959.

Wang, G. H。: Johns Hopk. Hosp. Bull. 40: 304, 1927 .

We11, M. H.: Cong. Intern. biochem., Rlosumbs Cormuns, 2nd Congress, Parls 67: 1952.

We1ss, J., Weiss, S. and We1ss, B.: Ann. No Y. Acad. So1. 80: $854,1959$.

White, A.: Phya101. Rev. 26: 574, 1946.

Wolffe, J. B. and Shub1n, H.: Cl1n. Med. 6: 1563, 1959.

Zb1adon, G. and Studer, A.: Ann. N. Y. Acad. So1. 80;

Zeller, E. A. and Barskg, J.: J. Lab. clin. Med. 4.0: 965, 1952 .

Zeller, E. A., Barsky, J., Fouts, J. R., Kirehelmer, W. F. and Van Orden, L. S.: Experient1a 2: 349, 1952 .

Zeller, E. A., Barsky, J., Berman, E.R. and Fouts, J. R.: J. Pharmaool. 106: 427, 1952b.

Z110, M.: Fed. Proo. 18: 359, 1959.

Z110, M.: Endocrinology 66: 311, 1960.

Z1le, M. and Lardy, H. A.: Arch. Blochem. Blophys. 82: 411, 1959. 
APPENDIX

64 
65

TABLE I-A

Concentration of standard dextrose

solutions and corresponding colorimeter readings

\begin{tabular}{|c|c|c|c|}
\hline $\begin{array}{l}\text { Concentration } \\
\text { of Dextrose } \\
\text { (mg/100ml) }\end{array}$ & $\begin{array}{l}\text { Sample } \\
\text { Number }\end{array}$ & $\begin{array}{l}\text { Optical } \\
\text { Density } \\
\text { Reading }\end{array}$ & $\begin{array}{l}\text { Mean } \\
\text { Read Ing }\end{array}$ \\
\hline 210 & $\begin{array}{c}\text { Blank } \\
1 \\
2 \\
3 \\
3 \\
4 \\
5\end{array}$ & $\begin{array}{l}0.00 \\
0.47 \\
0.46 \\
0.45 \\
0.47 \\
0.47\end{array}$ & 0.47 \\
\hline 180 & $\begin{array}{c}\text { Blank } \\
1 \\
2 \\
3 \\
4 \\
5 \\
\end{array}$ & $\begin{array}{l}0.00 \\
0.39 \\
0.40 \\
0.37 \\
0.38 \\
0.36\end{array}$ & 0.38 \\
\hline 150 & $\begin{array}{c}\text { Blank } \\
1 \\
2 \\
3 \\
4 \\
5\end{array}$ & $\begin{array}{l}0.00 \\
0.36 \\
0.35 \\
0.35 \\
0.35 \\
0.34\end{array}$ & 0.35 \\
\hline 100 & $\begin{array}{c}\text { Blank } \\
7 \\
2 \\
3 \\
4 \\
5\end{array}$ & $\begin{array}{l}0.00 \\
0.21 \\
0.24 \\
0.21 \\
0.22 \\
0.22\end{array}$ & 0.22 \\
\hline 90 & $\begin{array}{c}\text { Blanik } \\
1 \\
2 \\
3 \\
4 \\
5\end{array}$ & $\begin{array}{l}0.00 \\
0.15 \\
0.15 \\
0.16 \\
0.14 \\
0.15\end{array}$ & 0.25 \\
\hline 60 & $\begin{array}{c}\text { Blank } \\
1 \\
2 \\
3 \\
4 \\
5\end{array}$ & $\begin{array}{l}0.00 \\
0.13 \\
0.11 \\
0.14 \\
0.10 \\
0.12\end{array}$ & 0.12 \\
\hline
\end{tabular}




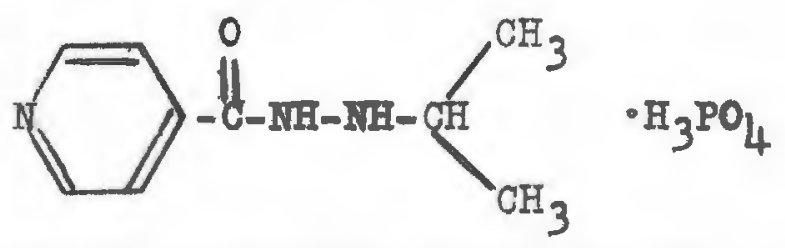

Iproniaz1d

(1-1son 1ootinyl-2-1sopropy Ihydrazino phosphate)

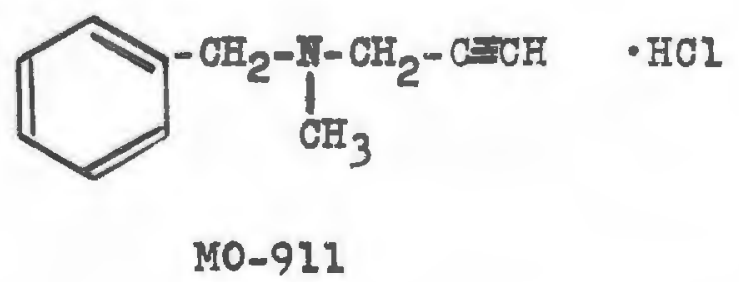

(N-benzyl-N-methyl-2-propynglamine hydrochloride)

FIG. I-A. Graph10 configurations of the MAO Inhibltors employed in the study. 

From the Department of Pharmacology, University of Rhode Island, College of Pharmacy, Kingston, Rhode Island, U.S.A.

THE INFLUENCE OF THYROTD FEEDING ON THE PHARMACOLOGIC ACTIONS OF SOME MONOAMINE OXIDASE INHIBITORS $(1)$

\section{By}

Richard N. Carrier (2) and Paul V. Buday (3)

(1) This investigation was supported in part by a U.S. Public Health Service research grant (MY-4435) from the National Institute of Mental Health.

(2) Submitted by R. N. Carrier to the Division of Graduate Studies of the University of Rhode Island in partial fulfillment for the degree of Master of Science (Phamacology), 1961.

(3) Present address: Medical Communication Department, Medical Research Section, Iederle Laboratories, a Division of American Cyanamid Company, Pearl River, New York, U.S.A. 
It is well-established that the calorigenic, metabolic, and hemodynamic effects of norepinephrine and epinephrine are diminished or lacking in hypothyroid animals (Sawyer and Brown, 1935; Raab, 1945; Brewster, 1956). On the other hand, although there are some contraindications as to an enhancement of native sympathomimetic amine activity during hyperthyroidism (Macmillan and Rand, 1962), thyroid hormone generally potentiates the action of epinephrine on oxygen consumption and basal metabolic rate (Lardy, 1957), and heart rate (Sawyer and Brom, 1935; Hoffmann et al., 1957; Gravenstein and Thier, 1960). The potentiation of epinephrine's activity on the resting blood pressure (Gerlei, 1938; Spinks, 1952) of rabbits and on isolated swine arteries (Smith, 1954) and rabbit duodenum (Trendelenburg, 1953) has been interpreted in terms of a decrease in tissue monoamine oxidase (MAO) levels or a reduction in the enzyme's activity engendered by thyroid hormone.

Similarly, Burn and Marks (1925) have found that feeding thyroid to rabbits increases their sensitivity to epinephrine-induced hyperglycemia. This hormonal "priming" effect was later ascribed to the ability of thyroid hormone to diminish hepatic MAO activity (Spinks and Burn, 1952; Trendelenburg, 1953). Although there have been some reports to the contrary (Westermann, 1956; Holtz et al., 1956), this in vivo inhibitory action of thyroid hormone on hepatic MAO in rodents seems reasonably well-established by the work of zile and Lardy (1959, 1960), Calvert and Brody (1961), and Novick (1961). The hypothesis of Zile and Lardy (1959) that thyroid hormone regulates the biosynthesis of hepatic MAO has been supported by others (Ozaki et al., 1960). 
Further, whether the action of thyroid hormone is primarily upon MAO, 0-methyltransferase, or both, the fact remains that the administration of thyroid elevates catecholamine blood levels and increases their urinary excretion in animals (Zile and Lardy, 1959; D'Iorio and Leduc, 1960) and man (Diwan1 et al., 1960).

Bailey et al. (1959), KIine (1961), and Saunders (1962) have found that melancholic patients medicated for several days with both thyroid and iproniazid, an irreversible MAO Inhibitor and antidepressant, paradoxicaliy became apathetic and sluggish, ashen and cyanotic in appearance, and showed evidence of a fall in blood pressure. These adverse behavioral and gross physical or somatic effects necessitated withdrawal of the antidepressive agent.

In light of these seemingly peculiar and contradictory effects, the present investlgation was designed in preliminary fashion to determine what action thyroid feeding had, if any, on the pharmacodynamic actions of irreversible acting MAO inhibitors, and to attempt to explain, at least on a gross somatic basis, the reason for the reported psychotherapeutic incompatibility between concurrent thyrold and MAO inhibitor medication.

\section{MAITERIALS AND METHODS}

\section{Animals. -}

Sixty maie albino Wistar rats, ranging in weight from 170-210 gm, were randomly divided into 10 groups of 6 animals each. All groups were caged separately and the enviromental temperature was kept between 25-270 C throughout the study. 
Drugs and Dosage Protocol.-

Iproniazid (I-isonicotinyl-2-isopropylhydrazine) phosphate (Marsilid(I)) and pargyline (N-benzyl-N-methyl-2-propynylamine hydrochloride; MO-91I; Eutonyl(2)) were used as irreversible MAO inhibitors. Both arugs were freshly prepared by dissolving the respective salts in physiological saline solution. Injections were given intraperitoneally. Starting on the eighth day of drug diet feeding, animal groups I and VII received $250 \mathrm{mg} / \mathrm{Kg}$ of iproniazid phosphate, and groups II and VIII received $175 \mathrm{mg} / \mathrm{Kg}$ daily. Groups III and IX received $25 \mathrm{mg} / \mathrm{kg}$ of pargyline hydrochloride, and IV and $\mathrm{X}$ received $10 \mathrm{mg} / \mathrm{Kg}$ daily. These latter doses were selected because pargyline in vitro is almost 8 times (Taylor et al., 1960) and in vivo (intraperitoneally) about 12 times more potent an irreversible MAO inhibitor in the rodent than iproniazid (Everett, 1962).

The remaining two groups ( $V$ and $V I$ ) were not medicated with the synthetic enzyme inhibitors.

\section{Diet and Feeding Protocol.-}

Control group V, which received neither an MAO inhibitor nor thyroid substance, was given Purina Lab Chow (Ralston Purina Co.) ad libitum in a special retabletted form. A $2 \%$ thyroid drug diet was prepared by homogeneously combining desiccated thyroid U.S.P., with the powdered lab chow

(1) Registered trademark of Hoffmann-Ia Roche, Inc., U.S.A.

(2) Registered trademark of Abbott Laboratories, U.S.A. 


$$
-4-
$$

and retabletting the granulation using suitable excipients. Incorporation of thyroid substance into the diet of the rats was felt most suitable in that it would allow gradual medication and continuous absorption to take place.

Initially, all 60 rats were fed the control diet for 7 days. On day 8 , groups I through $V$ were continued on this diet while groups VI through $X$ were fed the thyroid ration. Consequently, groups VII and VIII receiving iproniazid also received $2 \%$ thyroid, while groups IX and $X$ were fed the thyroid diet and received daily injections of parsyline. All animals were maintained on their respective diets for an additional 21 days or, where fatalities occurred, until the entire group died. To prevent or retard vitamin A deficit and weight loss normally evoked by hyperthyroidism, as well as for purposes of dietary standardization, all animals were given orally 3 drops of Oleum Percomorphum (Mead Johnson) every third day. The animals had free access to water at all times.

\section{Histopathologic Studies. -}

Immediately after death or sacriflce, samples of liver, kidney, and spleen were removed from one or more representative animals of groups II, III, IV, and $V$. The tissues were fixed in Bouin's solution and, after preparation and section (10 microns), were stained with hematoxylin and eosin and examined for general morphologic changes.

\section{Blood Pressure Studies.-}

Indirect systolic blood pressures of each animal were taken daily using 
a precalibrated photoelectric tensometer; the technique of Kersten et al., (1947) was followed. Fright and other like interfering stresses were avoided by training all animals to accommodate the pressure cuff before beginning the drug studies. Direct instrument values were read in $\mathrm{mm}$ Hg; in no case were they read greater than the closest $5 \mathrm{~mm} \mathrm{Hg}$. When fatalities due to drug treatment occurred, readings were taken for not less than 3 surviving animals of the particular group. The normal, mean systolic blood pressure and standard deviation of the entire 60 rats was calculated. Confidence intervals were calculated according to standard statistical procedures (Ostle, 1954) for the true mean pressure of such untreated animals.

Urinary Dopamine Studies. -

Twenty-four hour urine samples from groups II, V, and VI were collected in $2 \mathrm{~N}$ sulfuric acid on the eighth and fifteenth days of drug administration. The pooled samples were filtered and processed for the extraction of catecholamines (Crawford and Law, 1958). An aliquot was passed through a strongly acidic, cationic exchange resin (Dowex 50W, $\mathrm{X}-8, \mathrm{Na}^{+}$form) column, and the dopamine was eluted from the resin by $8 \mathrm{ml}$ of $2 \mathrm{~N}$ hydrochloric acid (Bertler et al., 1958). Dopamine concentrations were determined by using the trihydroxyindole-fluorlmetric method of Carlsson and Waldeck (1958) and an Aminco-Bowman spectrophotofluorometer (American Instmument Co.).

Fasting Blood Glucose Determinations.- 
and were made, immediately following blood pressure recordings, from lightly anesthetized (pentobarbital sodium, $20 \mathrm{mg} / \mathrm{Kg}$ i.p.) rats. All animals were fasted for 17 hours prior to the blood sampling. Blood glucose concentrations for each animal were determined colorimetrically (Nelson, 1944; Somogyi, 1945) using a precalibrated Spectronic 20 colorimeter (Bausch and Lomb) and 12.7 diameter cuvettes. Individual concentrations were read as optional density units, and these were transformed into $\mathrm{mg} / 100 \mathrm{ml}$ by referring to a calibration curve. The individual values were averaged to obtain group means, and standard deviations were calculated. Confidence intervals, as before, were calculated for the true, untreated, rat mean blood glucose concentration.

\section{RESULTS}

\section{General Observations.-}

The MAO inhibitor-treated animals exhibited a somewhat diminished random motor activity and were easier to handle than unmedicated controls. Within 3-4 days, all thyroid-fed rats became considerably irritable, but in those groups where both enzyme inhibitor and thyroid were administered the hyperexcitability was less apparent. In fact, the sluggishness and asthenia of these dually medicated animals became increasingly pronounced as the drug treatments continued.

Food and water consumption was generally decreased in the MAO inhibitortreated groups, but this effect was less pronounced with the pargyline treatments. Thyroid-fed animals ate and drank avidly, while hyperthyroid rats given either of the enzyme inhibitors seemed restrained in their 
feeding habits. Death of the MAO inhibitor-treated anima?s was always preceded by complete inanition. Mean body weights of euthyroid rats under iproniazid medication fell steadily especially during the first 9 days of injection, while the body weights of similar animals under pargyline showed either slight decreases or moderate increases. A relatively slow, but progressive weight decline also occurred in the thyroid-fed rats after an initial 5-day increase. Untreated animals maintained on the control diet showed normal weight gains, and at the end of 3 weeks weighed, on the average, 45 gm more than the hyperthyroid control animals. A sporadic incidence of diarrhea was common in all enzyme inhibitor-treated rats; it was particularly evident in thyroid-fed animals. The feces of MAO inhibitor-treated rats were coated with considerable intestinal mucus. Considerable blood was noted in urine samples from iproniazid-treated rats; blood specimens contained laked erythrocytes. Iproniazid-medicated rats regularly showed reddish-colored ocular discharges that resembled dried blood; this effect was less frequently observed with pargyline. An abnormal degree of salivation occurred with both iproniazid and pargyline treatments in euthyroid and hyperthyroid animals, but this effect appeared more prevalent with the nonhydrazine compound.

\section{Subacute Toxicity.-}

Symptoms of iproniazid toxicity rapidly developed. In group I, given $250 \mathrm{mg} / \mathrm{Kg}$ of iproniazid daily, a few rats died on the second day of injection; all animals of this group died within 8 days (Table I). 
[Table I Here]

The lower dose of iproniazid (175 mg/Kg) was considerably less toxic. The feeding of $2 \%$ desiccated thyrold concurrently with injected iproniazid at both dose levels (groups VII and VIII), however, hastened their deaths 3- to 4-fold. Although the feeding of thyroid alone (group VI) or the administration of pargyline at 10 (group IV) and $25 \mathrm{mg} / \mathrm{Kg}$ (group III) alone caused no fatalities, the concurrent administration of both thyroid and MAO inhibitor (groups IX and $X$ ) resulted in the deaths of all animals within 15 days.

\section{Histopathologic Stuales.-}

Livers removed from rats which had received lproniazid for 21 days showed small superficial lesions. The kidneys of these animals appeared abnormally dark red in color; spleens, on the other hand, were almost black. Histologic examination of these organs revealed hepatocellular damage, renal tubule necrosis, and considerable erythrocyte fragmentation in the spleen. Rats sacrificed after 21 days of pargyline dosing exhibited none of these tissue changes; several of the spleens in these groups, however, appeared abnormally dark red in color. Tissues from thyroid-MAO inhibitor-treated animals were not examined. 
Table I

Subacute Toxicity in Rats of Desiccated Thyroid, Iproniazid, and Pargyline, Alone and in Combination

\begin{tabular}{|c|c|c|c|}
\hline Group & $\begin{array}{l}\text { Daily Intraperitoneal Dose } \\
\text { of MAO Inhibitor }(\mathrm{mg} / \mathrm{Kg})\end{array}$ & Diet & Deaths \\
\hline$I$ & $\underset{250}{\text { Iproniazid } \mathrm{PO}_{4}}$ & Control & All within 8 days \\
\hline II & $\underset{175}{\text { Iproniazid } \mathrm{PO}_{4}}$ & Control & 2 within 21 days \\
\hline III & $\begin{array}{c}\text { Pargyline HCl } \\
25\end{array}$ & Control & Ione \\
\hline IV & $\begin{array}{l}\text { Pargyline } \mathrm{HCl} \\
10\end{array}$ & Control & None \\
\hline V & None & Control & None \\
\hline VI & None & 2 \% Thyroid & None \\
\hline VII & 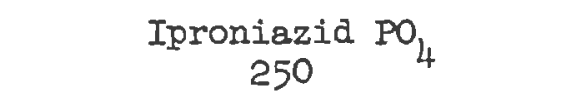 & 2 \% Thyroid & All within 2 days \\
\hline VIII & $\underset{175}{\operatorname{Iproniazid}} \mathrm{PO}_{4}$ & $2 \%$ Thyroid & All within 6 days \\
\hline IX & $\underset{25}{\text { Pargyline } \mathrm{HCl}}$ & $2 \%$ Thyroid & All within 14 days \\
\hline$x$ & $\begin{array}{c}\text { Pargyline } \mathrm{HCl} \\
10\end{array}$ & $2 \rho_{p}^{\prime}$ Thyroid & All within 15 days \\
\hline
\end{tabular}


Blood Pressure and Urinary Dopamine Studies.-

The normal, mean systolic blood pressure and standard deviation (S.D.) of the 60 rats were calculated to be $110 \pm 7.66 \mathrm{~mm} \mathrm{Hg}$. Confidence limits (99\%) of 107.4-112.6 m Hg were calculated for the true mean in the untreated rats.

It can be seen from Figures 1-4 that a slight time factor exists in the response to drue or thyroid treatments. Moreover, most animals in the MAO inhtbitor groups did not show synchronous changes in blood pressure so that the intragroup variability, for any given day, was. generally more marked than that observed in control or pretreatment periods. Therefore, the following very conservative statistical procedure and reasoning was adopted: the S.D. of the mean of a sample of 6 animals, draw from the same population as the 60 control observations, would be the S.D. of the general population divided by the square root of 6 , i.e., 2.4495. Any mean of a sample of size 6 that differed from the population mean by more than 2.58 times the S.D. divided by 2.4495 would be significantly different at the I $\%$ level. When, as in the present situation, the true S.D. is not known, the estimated value $(7.66 \mathrm{~mm} \mathrm{Hg})$ may be used if the normal distribution critical value of 2.58 is replaced by the critical value of student's " $t$ " with the appropriate number of degrees of freedom, i.e., d.f. = 59; $" t "=2.660$. Thus, making the conservative assumption that the true mean is as Iikely to be at the upper boundary of the confidence interval as at its center, any mean of a sample of 6 that lies outside the calculated confidence interval by more than 2.660 times the S.D. divided by 2.4495 is significantly different from the true mean of the control population, 
at the 1 of level, if indeed the confidence interval does contain the true mean. Since we have $99 \%$ confidence that it does contain the mean, we can say with not less than 98.01 \% confidence that any such outlying small sample (6) mean comes from a population other than that of the untreated rats, and is, therefore, a true difference. Applying these calculations, 98 \% "critical limits" were determined for the control mean blood pressure and are represented by the continuous, horizontal lines in Figures 1-4.

The 24-hour pooled urinary dopamine concentrations of the nonmedicated controls (group V) were estimated on days 8 and 15 ; these quantities were found to be 362 and $475 \mu \mathrm{g} / 1$ of urine respectively. In our laboratory, these amounts are considered representative. The mean arterial blood pressures taken on these same days were $110 \pm 8.5$ and $112 \pm 7.9 \mathrm{~mm} \mathrm{Hg}$ respectively.

As shown in Figure 1, iproniazid at the $175 \mathrm{mg} / \mathrm{Kg}$ daily dose level (group II) uniformly caused statistically significant pressor effects after day 1 .

\author{
[Figure 1 Here]
}

Blood pressures continued to rise until day 5 when they plateaued. On days 9 and 10, the systolic pressures fell precipitously and, except for a rise on day 1 of treatment, became rather erratic and remained only barely above or within normotensive levels for the remainder of the treatment period. The urinary dopamine level for this same group was almost 
twice the normal on day 8 . On day 15, where the mean blood pressure, surprisingly enough, was almost normal (116 $\pm 27.0 \mathrm{~mm} \mathrm{Hg})$, the excretion was approximately 5 times greater than customary.

The blood pressure effects of pargyline at the $25 \mathrm{mg} / \mathrm{Kg}$ daily dose level are shown in Figure 2.

[Figure 2 Here]

In contrast with iproniazid, pargyline produced an initial, transient hypotensive effect that reached a maximum on day 3. After day 6 , mean pressures rose for 3 days and attained a mean peak of about $155 \mathrm{~mm} \mathrm{Hg}$ on day 9. Pressures fell on day 10, but they stabilized slightly above normotensive levels thereafter. At the lower dose (10 mg/Kg daily, group IV), pargyline elicited somewhat similar blood pressure effects, but the mean, peak pressor effect (163 mm Hg) did not occur until day 13. On days 16 and 17 , mean pressures fell to about $127 \mathrm{~mm} \mathrm{Hg}$, whereupon a pressor effect (up to $145 \mathrm{~mm} \mathrm{Hg}$ ) again supervened on day 18 that persisted until the end of the treatment period.

The feeding of desiccated thyroid caused a definite, gradually developing pressor effect first noted on day 4; peals pressures of about $160 \mathrm{~mm} \mathrm{Hg}$ occurred on day 16 (Figure 3). 
Individual blood pressures in this group were much less variable than in any of the MAO inhibitor-treated animals. There was no evidence of a return to normotensive levels while thyroid feeding was continued. Irrespective of the pressor responses, pooled dopamine excretion values on days 8 and 15 were 482 and $517 \mu \mathrm{g} / 1$ of urine respectively. These values for the thyroid-fed group were not considered abnormally high.

The feeding of $2 \%$ thyroid to iproniazid-medicated animals (Groups VII and VIII) decimated the respective groups in such rapid fashion (Table I) that the recording of the erratic blood pressures and blood glucose concentrations was made almost impossible and gave little basis for interpretation. Figure 4 shows the blood pressure effects in rats treated with $25 \mathrm{mg} / \mathrm{Kg}$ of pargyline and $2 \%$ thyroid.

\section{[Figure 4 Here]}

It is obvious that although the variation in blood pressures among the individual animals of the group was large, a definite pressor effect began 
after the second day and, except for a fall on day 9, was maintained until day 12 when the blood pressures of the surviving animals of the group fell sharply thereafter to normotensive or slightly hypotensive levels. No evidence of any initial transient fall in blood pressure as in the pargylinetreated rats was detected.

The collateral treatment of rats with $10 \mathrm{mg} / \mathrm{Kg}$ of pargyline and 2 of thyroid gave effects roughly equivalent to the higher dose of pargyline and thyroid feeding. The peak mean pressure occurred on day 6 and thereafter fell slowly, but erratically, to a minimum of $88 \mathrm{~mm} \mathrm{Hg}$ on day 12 . The blood pressures stabilized at about $105 \mathrm{~mm} \mathrm{Hg}$ thereafter. The entire group died between days 14 and 15 .

Fasting Blood Glucose Studies.-

The blood glucose mean and standard deviation of the 60 control measurements were calculated to be $104 \pm 11.20 \mathrm{~mm} \%$. Confidence limits ( $99 \%$ ) of 107.9-100.1 $\mathrm{mg} \%$ were calculated for the true mean in the untreated rats. Employing the same statistical reasoning as adopted for the blood pressure studies, the 98 o "critical limits" were determined for the control mean and are represented by the broken, horizontal lines in Figures $1-4$.

As readily evident from the figures, 3-week daily treatment with either one of the enzyme inhibitors and/or desiccated thyroid generally failed to statistically modify mean blood glucose concentrations although fluctuations did occur; only in those animals near death from MAO inhibitor treatment did the concentrations fall. 


\section{DISCUSSION}

Although not quantitated, both hydrazide and nonhydrazide MAO inhibitors in the doses employed did not elicit any gross evidence of hyperexcitability or an increase in general random motor activity. Certainly one explanation for the generalized depression of activity may be simply a reflection of subacute toxicity. The hyperirritability of the hyperthyroid rats, as well described by a number of other workers (French, 1912; Watanabe and Nomura, 1937), was completely reversed in those aninals receiving both thyroid and an MAO inhibitor. The somato-motor weakness and sluggishness of these animals most likely is a reflection of general apathy and an index of an accelerated toxicity in animals whose general metabolism has a]ready been seriously disturbed.

The general increase in food and water intake of the thyroid-fed rats, irrespective of their hampered weight gains, agrees with the reports of Carlson et al. (1912), French (1912), and Barker (1951); these effects are undoubtedly accounted for by an increased metabolic rate and the constant need to satisfy such a demand. No doubt the collateral use of vitamins $A$ and $D$ offset, to an extent, some of the adverse effects of high doses of thyroid. The exaggerated weight decline in the anirials dosed with both hormone and an MAO inhibitor is most likely a nonspecific symptom of drug-induced toxicity.

The diarrhea noted in almost all thyroid-fed rats is a commonly observed untoward effect (gastrointestinal hypermotility) in thyroid-sensitive animals (Carlson et al., 1912; French, 1912). The marked diarrhea in 
the MAO inhibitor-treated rats is difficult, however, to reconcile with the frequently reported constipating effect of iproniazid in man (0'Connor et 르., 1953; Alexander and Berkeley, 1959; Weiss et al., 1959). The elimination of fecal matter coated with mucus was also a common finding in the iproniazid-and pargyline-medicated rats. Hypermucosity has been reported with the clinical use of other MAO inhibitor antidepressants (Sainz, 1959); this side effect in both man and rat may possibly indicate incipient gastroenteritis.

Hematuria and the presence of laked erythrocytes were commoniy found in blood samples from iproniazid - but not parbyline-treated rats. The hemolytic effects of hydrazine and its analogues are well-documented, and the above toxicity we observed may be related to the hydrazine moiety of iproniazid. Hemolytic anemia has only rarely been reported to occur in man (O'Connor et al., 1953) with iproniazid use. Moreover, histopathologic studies in other rodents medicated with relatively high doses of hydrazides have shown signs of increased erythrocyte destruction, as evidenced by hemosiderosis of the kidney, liver, and spleen, and hyperemia or darkening of the latter organ (Benson et al., 1952; Zbinden and Studer, 1959). These reports, the hemolysis noted in our study, and the reported hepatic and splenic accumulation of iproniazid after parenteral administration (Koechlin and Iliev, 1959) may explain the organ darkening and injury observed by us. The lack of gross hemolytic changes with pargyline contributes presumptively to the impression that such toxicity is most probably due to the hydrazine molety of iproniazid. A rather singular toxic effect was the reddish ocular discharges (chromodacryorrheaIike) that occurred with subacute administration of both iproniazid and 
pargyline. The only comparable effect, known to us, is the report of an ocular discharge of a porphyrin-like material in rats given subacute doses of etryptamine acetate, a new indole MAO inhibitor (Gray, 1961).

The rapid onset of iproniazid toxicity was not particularly surprising as the intraperitoneal doses used were very high. What was unexpected, however, were the rapidity and high incidence of fatalities in the simultaneously enzyme inhibitor- and thyroid-medicated rats. The administration of desiccated thyroid or thyroxine is known to modify the susceptibility of animals to the toxic effects of a number of arugs. Although large doses of thyroid may. produce liver damage (Barker, 1951), the rapid onset of toxicity and high incidence of fatality in those animals receiving either one of the synthetic MAO inhibitors and thyroid seems to imply that the metabolic effects of the latter accentuate the direct, subacute toxicity of large doses of the antidepressants. This assumption is further strengthened by our previous findings that hyperthyroidism increases the acute toxicity of pargyline in rats (Carrier and Buaay, 1961). Whether these toxic effects, acute or subacute, are in any way related to a combination of the in vivo MAO inhibitory effects of thyroid hormone and the synthetic enzyme inhibitors with a resultant elevation of catecholamines (Ieduc et al., 1955; Zile and Lardy, 1959) or serotonin (Put and Hogenhuis, 1962), no conclusion can be drawn at this time; further work (behavioral and enzymatic), however, is in progress to study these possible causal relationships. In any event, the stress of impending thyrotoxicosis in the MAO inhibitortreated animals in our study may, in some superficial fashion, parallel the clinical reports of a phamacotherapeutic incompatibility during 
simultaneous medication with thyroid extract and irreversible MAO inhibitors (Bailey et aI., 1959; Kline, 1961).

The blood pressure responses to prolonged adminlstration of both iproniazid and pargyline showed large variations and may be explained on the basis of oscillating responses and the small sample size. Because of the great dose difference between iproniazld and pargyline, little comparative importance can be given to the latter drug's minor primary hypotensive effects. What is perhaps of some importance is the fact that a pressor effect induced by repeated dosing with both drugs did occur. Hypotension is a common side effect during protracted medication with the MAO inhibitors and when given acutely to animals in relatively low doses (Cahn and Herold, 1962). Single, massive parenteral doses of iproniazid, however, cause a rise in rabbit blood pressure (De PaIol and Iemberg, 1962). Dopamine, the biogenic precursor of norepinephrine and epinephrine, is a weak pressor material in the rat (Vogt, 1959). Its metabolism is reduced or blocked by MAO inhibitors (Horwitz et al., 1962), and we speculated that the pressor effects persisting from the second to eighth day with iproniazid dosing might be correlated with the urinary excretion of the catecholamine. No such correlation was able to be made, however. Dopamine excretion values were elevated approximately $100 \%$ on day 8 when the mean systolic blood pressure was some $55 \mathrm{~mm} \mathrm{Hg}$ above the normal, but on day 15, when dopamine excretion values were increased about $400 \%$, the mean blood pressure was within normal limits.

Hypertension is a frequent concomitant of clinical hyperthyroidism (Logan, 
1930). In rats, thyroxine-induced hypertension was explained by Samiy (1952) as due to an altered receptor sensitivity to dopamine. Dopamine excretion was not significantly elevated in our thyroid-fed rats, however, and hence the pressor effects in the hyperthyroid rats may have no relationship to this catecholamine. Furthermore, hyperthyroidism inhibits hepatic dopa decarboxylase, the enzyme responsible for the rapid conversion of 3,4dihydroxyphenylalanine (dopa) to dopamine (Clark, 1959). Considering this, and the avidity of MAO for dopamine, it is tempting to speculate about these mutually antagonistic properties of thyrold hormone on those enzymes playing a significant role in the biotransformation of dopamine and the reason for the normal dopamine excretion values in hyperthyroid rats.

Whereas the daily injection of pargyline alone uniformly elicited a slight, primary depressor response lasting as long as the fourth day of medication, the administration of pargyline to thyroid-fed rats obliterated this initial effect; a pressor effect was evoked as early as day 3 and although temporary, the pressor effects were somewhat greater than that with either hormone or drug given alone. The sudden and precipitous fall in blood pressure occurring on days 11 and 12 in those groups (IX and $X$ ) receiving both pargyline and thyroid cannot be readily explained. Certainly cardiovascular collapse, a prelude to death, is a possibility.

Parenteral administration of hydrazine sulfate in large doses elicits hypoglycemia in animals (Underhill, 19l1), and clinical reports of diminished blood gluçose levels during iproniazid therapy have been published (Weiss et 르., 1959; Aksel, 1960). Contrary to expectations, however, no statistically 
signiflcant blood glucose changes occurred with iproniazid; no significant changes occurred with pargyline. Similarly, thyroid feeding elicited no blood glucose changes in rats: ordinarily the feeding of large quantities of thyroid to dogs and rats (Houssay, 1944) or hyperthyroidism in man (Geyelin, 1915) results in a definite hyperglycemia. The reason for our inability to duplicate these effects in our study is obscure.

\section{SUMMARY}

Daily intraperitoneal injections of massive doses of iproniazid phosphate and high doses of pargyline hydrochloride for as long as three weeks markedly reduced the general motor activity and body weight of male rats. Both of these effects, the general malaise, and the incidence of mortality was increased by the daily feeding of a high concentration of desiccated thyroid. Limited gross and microscopic studies showed that iproniazid $(175 \mathrm{mg} / \mathrm{Kg}$ daily) caused hepatic, splenic, and renal injury, and hemolysis. Pargyline (10 and $25 \mathrm{mg} / \mathrm{Kg}$ daily), other than causing splenic darkening, showed no comparable effects.

Although exhibiting large fluctuations, systolic blood pressures rose rapidly, but only temporarily, in iproniazid-treated rats. Significant pressor effects in pargyline-dosed rats began only after 7 days. The collateral feeding of thyroid to pargyline-treated animals accelerated the onset and accentuated the pressor effects. The feeding of thyroid alone elicited a slowly developing and uniform pressor effect. Limited dopamine studies in normal, Iproniazid-and thyroid-nedicated rats showed that there was no apparent correlation between the pressor responses and the excretion 
$-20-$

of dopemine. No significant changes in fasting blood glucose concentrations occurred during subacute administration of the MAO inhibitors or thyrold alone, nor when the treatments were concurrent. 


\section{ACKNOWLEDGMENTS}

The iproniazid phosphate was generously supplied by Dr. Robert E. Dixon, Hoffmann-Ia Roche, Inc., and the pargyline hydrochloride was furnished through the courtesy of Dr. Guy M. Everett of Abbott Laboratories. The assistance of $\mathrm{Dr}$. David R. DeFanti in performing the urinary dopamine studies is gratefully acknowledged. The authors are also grateful to Mr. William J. Dewey, Lederle Laboratories, for statistical advice. 
REIERENCES

1.- Aksel, I.S. Wien. Med. Wschr., 1960, 110, 713.

2.- Alexander, I. and Berkeley, A.W. Ann. N. Y. Acad. Sci., 1959, 80,669 .

3.- Bailey, S.d'A., Bucci, I., Gosline, E., Kline, N.S., Park, I.H., Rochlin, D., Saunders, J.C. and Vaisberg, M. Ioid., 1959, 80,652 .

4.- Barker, S.B. Physiol. Rev., 1951, 31, 205.

5.- Benson, W.M., Stefko, P.I. and Roe, M.D. Amer. Rev. Tuberc., 1952, 65, 376 .

6.- Bertler, A., Carlsson, A. and Rosengren, E. Acta Physiol. Scand., $1958,44,273$.

7.- Brewster, W.R., Jr., Isaacs, J.P., Osgood, P.F. and King, T.L. Circulation, 1956, 13, 1.

8.- Burn, J.H. and Marks, H.P. J. Physiol. (Iond.), 1925, 60, 131.

9.- Cahn, J. and Herold, M.M. Chemotherapia (Basel), 1962, 4, 262. 10.- Calvert, D.N. and Brody, T.M. J. Pharmacol. Exp. Ther., 1961, 134,304 .

11.- Carlson, A.J., Rooks, J.R. and McKie, J.F. Amer. J. Phys1ol., $1912,30,129$. 
12.-Carlsson, A. and Waldeck, B. Acta Physiol. Scand., 1958, 44, 293.

13.- Carrier, R.I. and Buday, P.V. Nature (Iond.), 1961, 191, 1107.

14.- Clark, W.G. Pharmacol. Rev., 1959, 11, 330.

15.- Crawford, T.B.B. and Lew, W. J. Pharm. Pharmacol., 1958, 10, 179.

16.- De Palol, J. and Lemberf, A. Nature (Iond.), 1962, 194, 482.

17.-D'Iorio, A. and Leduc, J. Arch. Biochen., 1960, 87, 224.

18.- Diwani, M., Talaat, M., Mokhtar, N. and Salam, I.A. Acta Endocr. (Kbh.), 1960, 51 (Suppl.), 1199.

19.- Everett, G.M. Abbott Laboratories, Personal Comunication, 1962.

20.- French, H.E. Amer. J. Physiol., 1912, 30, 56.

21.- Gerlei, F. Endokrinologie, 1938, 19, 387.

22.- Geyelin, H.R. A.M.A. Arch. Intern. Med., 1915, 16, 975.

23.- Gravenstein, J.S. and Thier, M.D. The Pharmacologist, 1960, 2, 65.

24.- Gray, J.E. J. Neuropsychiat., 1961, 2, S163.

25.- Hoffmann, F., Hoffmann, E.J. and Talesnik, J. Amer. J. Physiol., $1957,148,689$.

26.- Holtz, P., Stock, K. and Vestermann, E. Arch. Exp. Path. Piarmarol., 1956, 228, 322 . 
27.- Horwitz, D., Fox, S.M., III and Goldberg, L.I. Circulat. Res., $1962,10,237$.

28. - Houssay, B.A. Endocrinology, 1944, 35, 158.

29.- Kersten, H., Brosene, H.G., Jr., Ablondi, F. and SubbaRow, Y. J. Iab. Clin. Med., 1947, 32, 1090.

30.- Kline, N.S. J. Neuropsychlat., 1961, 2, S15

31.- Koechlin, B. and Iliev, V. Amn. N. Y. Acad. Sc1., 1959, 80, 86t.

32.- Lardy, H.A. Hormonal Regulation of Energy Metabolism, 1957, I.W. Kinsell, Ed., pp. T-72, Charles'C. Thomas Co., Springfield.

33.- Ieduc, J., Dubreuil, R. and D'Iorio, A. Canad. J. Biochem., 1955, 33, 283 .

34.- Logan, R.E. Grace Hosp. Bull., 1930, 14, 18.

35.- Macmillan, W.H. and Rand, M.J. J. Pharm. Phamacol., 1962, 14, 257.

36. - Nelson, N. J. Biol. Chem., 1944, 153, 375.

37.- Novick, W.J., Jr. Endocrinology, 1961, 69, 55.

38.- O'Connor, J.B., Howlett, K.S., Jr. and Wagner, R.R. Amer. Rev. Tuberc., 1953, 68, 270.

39.- Ostle, B. Statistics in Research, 1954, The Iowa State College Press, Ames. 
40.- Ozaki, M., Weissbach, I1., Ozaki, A., Witkop, B. and Udenfriend, S. J. Med. Pharm. Chem., 1960, 2, 591.

4I.- Put, T.R. and Hogenhuis, L.A.H. Acta Physiol. Pharmacol. Neerl., $1962,10,343$.

42.- Raab, W. J. Iab. Clin. Med., 1945, 30, 774.

43.- Sainz, A. Ann. N. Y. Acad. Sci., 1959, 80, 780.

44.- Samiy, A.E. Fed. Proc., 1952, 11], 136.

45.- Saunders, J.C. Rockland State Hospital, Personal Comrunication, 1962 .

46.- Sawyer, M.E.M. and Brow, M.G. Amer. J. Physiol., 1935, 110, 620.

47.- Smith, D.J. Amer. J. Physiol., 1954, 177, 7.

48.- Somogyi, M. J. Biol. Chem., 1945, 160, 61.

49.- Spinks, A. J. Physiol. (Iond.), 1952, 117, 35 P.

50.- Spinks, A. and Burn, J.H. Brit. J. Pharmacol., 1952, I, 93.

51.- Taylor, J.D., Wykes, A.A., Gladish, Y.C. and Martin, W.B. Nature (Lond.), 1960, 187, 941.

52.- Trendelenburg, U. Brit. J. Pharmacol., 1953, 8, 454.

53.- Underhill, F.P. J. Biol. Chem., 1911, 10, 159. 
54.- Vogt, M. Pharmacol. Rev., 1959, II, 249.

55.- Watanabe, T. and Nomura, Y. Psychol. Abst., 1937, 11, 18.

56.- Weiss, J., Weiss, S. and Weiss, B. Ann. N. Y. Acad. Bci., 1959, 80,854 .

57.- Westemann, E. Arch. Exp. Path. Phammakol., 1956, 228, 159.

58.- Zoinden, G. and Studer, A. Ann. N. Y. Acad. Sci., 1959, 80, 873.

59.- Zile, M.H. Endocrinology, 1960, 66, 311.

60.- Zile, H. and Lardy, H.A. Arch. Biochem., 1059, 82, 41 . 
A method found simple and expeditious to produce an acceptable remade cchow tablet, using limited and easily accessible equipment, was to crush the hard, brittle pellets by use of a Wiley laboratory mill, passing the coarse material thence through a Mikro Samplmill (model 579A) to give a number 60 powder or finer. To each $100 \mathrm{~g}$ of this powder was added $40 \mathrm{ml}$ of a warm, freshly prepared, gelatin-acacia solution made by dissolving $10 \mathrm{~g}$ of Gelatin (granular) U. S. P. and $1 \mathrm{~g}$ of Acacia (powder) U. S. P. in $100 \mathrm{ml}$ of boiling distilled water. The binder and powders were then mixed thoroughly to form a damp mass. The latter was then sifted through a number 10 mesh brass screen to form granules. These particles were then passed through a number 20 mesh screen to obtain a finely granulated mass.

Using a hand driven, single punch, Stokes tablet machine (model A-3 Eureka) with a $1.27 \mathrm{~cm}$ standard concave punch and die set for maximum fill $(1.09 \mathrm{~cm})$, the damp granulation was compressed into $0.5 \mathrm{~g}$ convex tablets having $2.0 \mathrm{~mm}$ edge thickness. The pressure on the punch approximated 7.5 tons pertsquare inch. The tablets were allowed to dry and harden thoroughly at ambient room temperature (approximately $21^{\circ} \mathrm{C}$ ) for 36 hours or longer. 